\title{
Design of small molecule inhibitors of type III secretion system ATPase EscN from enteropathogenic Escherichia coli
}

\author{
Lukasz Bzdzion1,\#, Hanna Krezel1,\#, Karol Wrzeszcz1, Irmina Grzegorek1, Katarzyna Nowinska1, \\ Grzegorz Chodaczek ${ }^{1}$ and Wieslaw Swietnicki1,2匹
}

'Department of Biotechnology, Wroclaw Research Centre EIT+ Ltd., Wrocław, Poland; Institute of Immunology and Experimental Therapy of the Polish Academy of Sciences, Wrocław, Poland

Enteropathogenic $E$. coli (EPEC) is a human pathogen using type III secretion system for delivery of proteins directly into the human host. The system contains a single ATPase, EscN, which is essential for uncoupling of proteins from their complexes with chaperones before the delivery. The structure of EscN ATPase (PDB code: 2obm) was used to screen computationally for small molecule inhibitors blocking its active site. Two lead candidates were examined but only one, Compound 54, was selected for further optimization. After extended QSAR optimization, two derivatives were found to be competitive inhibitors of EscN capable of blocking ATPase activity with a $K_{\mathrm{i}}$ below $50 \mu \mathrm{M}$. One candidate, WEN05-03, with a $K_{\mathrm{i}}=16 \pm 2 \mu \mathrm{M}$, was also minimally toxic to mammalian cells as determined by other assays. In the cell infection model of HeLa cells with EPEC, Compound WEN05-03 completely blocked actin cluster formation at $100 \mu \mathrm{M}$ concentration, when analyzed by confocal microscopy. The second best inhibitor of EscN ATPase activity was WEN04-34 with a $K_{\mathrm{i}}=46 \pm 2 \mu \mathrm{M}$. However, the compound was highly toxic to the BALB/3T3 cell line. In summary, the work identifies a compound blocking bacterial ATPase in its active site without causing cellular toxicity to the host cells. It is the first report showing feasibility of using bacterial virulence system ATPase as a target for safe, non-toxic compounds and offering a proof-of-concept for non-antibiotic alternatives.

Key words: Escherichia coli (E. coli), type III secretion system (T3SS), enzyme inhibitor, small molecule

Received: 09 February, 2016; revised: 06 September, 2016; accepted: 22 September, 2016; available on-line: 18 November, 2016

e-mail: wieslaw swietnicki@hotmail.com

\#L.B. and H.K. contributed equally to the work.

Abbreviations: EPEC, enteropathogenic E. coli; EHEC, enterohemorrhagic E. coli; EMEM, Eagle's Minimum Essential Medium; FBS, fetal bovine serum; HBSS, Hank's Balanced Salt Solution; P. aer, Pseudomonas aeruginosa; S. ent, Salmonella enterica; SDS-PAGE, sodium dodecyl sulfate polyacrylamide gel electrophoresis; PFA, paraformaldehyde; T3SS, type III secretion system; tir, translocated intimin receptor; wt, wild type; Y. ent, Yersinia enterocolitica; Y. pt, Yersinia pseudotubeculosis; Y. pes, Yersinia pestis; S. fle, Shigella flexneri; DescN, deletion mutant escN of enteropathogenic $E$. coli

\section{INTRODUCTION}

Escherichia coli is the most predominant part of the commensal flora of humans. Most strains are nonpathogenic but some have acquired the ability to cause diseases. Such an acquisition is accompanied by changes in the genome and, consequently, the protein and sugar coats of the bacteria. Epidemiological classification of the pathogenic E. coli is based on $\mathrm{O}$ (somatic) and $\mathrm{H}$ (flagellar) surface antigens (Edwards \& Ewing, 1972; Orskov \& Orskov, 1992). Accordingly, there are 5 major types of the pathogenic E. coli: enterotoxigenic (ETEC), enteropathogenic (EPEC), enterohemorrhagic (EHEC), enteroaggregative (EAEC) and enteroinvasive (EIEC) (Nataro \& Kaper, 1998). From the point of invasion mechanisms, only ETEC does not possess type III secretion system (T3SS) (Nataro \& Kaper, 1998). In the case of EPEC, T3SS is essential for virulence (Gartner \& Schmidt, 2004; Iguchi et al., 2009).

Analysis of genomes of uropathogenic E. coli (UPEC), one of the most cost common pathogens encountered in hospital settings, showed absence of a type III secretion system or the common toxins associated with phages or plasmids in other E. coli (Welch et al., 2002; Wiles et al., 2008). Instead, the strains have many adhesion proteins essential for host penetration, autotransporters, iron sequestering systems from the host and other elements replacing the known pathogenicity island proteins. The known secreted toxins of UPEC are secreted by the type $\mathrm{I}$ or the type $\mathrm{V}$ secretory systems and include $\alpha$-hemolysin, responsible for host cell lysis, cytotoxic necrotizing factor 1, responsible for constant activation of Rho family GTPases, and Vat and Sat toxins responsible for cell swelling and vacuolation. The mechanism of virulence is more diverse in this case and not as wellknown as for the T3SS-containing pathogens.

There are 3 stages of infection by EPEC (Nataro \& Kaper, 1998). In the first stage, the is a nonspecific adhesion mediated by plasmid. The role of this adhesion is important for infection as deletion of genes responsible for the step severely reduce diarrhea in humans. In the second stage of infection, signal transduction, morphology of membranes around the bacteria changes due to the secreted proteins. The stage relies on a functional T3SS and deletion of ATPase abolishes signal transduction responsible for membrane morphology changes. In the third stage, the so-called "intimate adhesion", the bacteria adhere tightly to the host and are eventually internalized. However, EPEC is not an intracellular pathogen in contrast to Salmonella sp. and typically stays attached to mammalian gut epithelial cells during infection. T3SS is essential for this step and deletion of T3SS genes responsible for the intimate attachment (e.g., tir, int) abolishes diarrhea in animal models of disease.

T3SS is the major virulence system of pathogens responsible for transport of bacterial proteins (effectors) from bacterial cytosol directly into the host cell (Cornelis, 2006). Morphologically, the system resembles a large syringe with a base anchored in bacterial cytosol and the needle protruding through the membranes to 
the outside. The needle is hollow and has a diameter 2-3 $\mathrm{nm}$. Proteins are secreted through the needle most likely in a partially unfolded state due to the small diameter of the needle.

The EPEC is distinct among other pathogens due to its ability to secrete its own receptor, tir, which is inserted into mammalian cell membranes. Secretion of tir requires a functional ATPase as does secretion of almost any effector by EPEC. The bacteria has an intimin protein int on its surface which anchors the pathogen to the mammalian membrane through the tir protein. Upon anchoring, the membrane around bacteria forms pedestals composed of polymerized actin. Soon, the mammalian membrane engulfs the bacteria and the pathogen is transported inside the host in a vesicle. The mechanism allows pathogen to penetrate almost any mammalian cell.

The T3SS system is coded chromosomally in EPEC on pathogenicity islands LEE1-5. Structural proteins forming injectisome are also coded by the system and the injectisome assembly process proceeds in stages. Upon completion, the system stays dormant and is activated during infection.

The LEE1-5 islands also code for effectors Esp (E. coli secreted proteins) and chaperones cesAB/D/ $\mathrm{D} 2 / \mathrm{T}$, needed for stability of many effectors in bacterial cytoplasm. Additionally, the islands code for translocators EspB and EspD forming pore in mammalian cell membranes and EspA forming translocation tunnel in the needle of EPEC, as well as bacterial surface receptor int, the translocated intimin receptor tir and many other accessory proteins (Wong et al., 2011).

Each T3SS has a single ATPase, EscN for EPEC, which is responsible for uncoupling chaperones from effectors before transport through the needle (Blaylock et al., 2006; Sorge et al., 2006). In other T3SSs from animal pathogens, the analogous ATPases are InvC from the first pathogenicity island of Salmonella enterica (Eichelber et al., 1994) or the SsaN from the same pathogen but from the second pathogenicity island (Yoshida et al., 2014). Plant pathogens have also their own T3SSs and examples may be the $\mathrm{HrcN}$ proteins from Xanthomonas campestri vs. vesicatoria (Rosier et al., 2000) or Pseudomonas syringae pv. phaseolicola (Pozidis et al., 2003). The ATPase recognizes the loaded chaperone-effector complex (Chen et al., 2013) by signals different than those used for secretion. Assembly of the needle itself requires a functional ATPase (Diepold et al., 2010; Davis et al. 2010). One of the proteins secreted by EPEC is EspG.

The order of secretion is determined mainly by the function of secreted proteins. In general, the first group of secreted proteins contains the needle protein, then translocators and finally the effectors (Izore et al., 2011). In EPEC, the tir protein is translocated most efficiently into the cells after the apparatus is assembled (Millis et al., 2008). EspG and Map are translocated least efficiently (Millis et al., 2008) which correlates with their low protein levels within the bacteria. The results are consistent with other data showing low level of esp $G$ gene transcription (Umanski et al., 2002).

The details of injectisome assembly are not well understood. However, certain aspects have been elucidated due to the advances in structural biology of large macromolecular assemblies (Diepold et al., 2010) and work in other areas (Monjaras Feria et al., 2012; Diepold et al., 2011). Due to its conserved nature, function and importance for bacterial virulence, T3SS has been a target of non-antibiotic approaches to bacterial therapeutics (Keyser et al., 2008). The system itself is non-essential for pathogen's survival outside the host and development of drugs selectively blocking its function would avoid the resistance associated with normal use of antibiotics.

Strategies to block the system can be divided into two classes: a) non-specific strategies blocking the secretion process and b) specific strategies, blocking the function of selected targets within the system. The non-specific strategies are mainly found through phenotypic screening showing loss of transport and associated effects within the mammalian hosts (reviewed in: Marshall \& Finlay, 2014). Such strategies suffer mostly from the lack of structural information about the target and, unfortunately, may lead to artifacts caused by blocking other processes important for pathogen's survival (MartinezArgudo et al., 2013).

The rational design of drugs relies on structural information on the target and typically allows for a better refinement, not to say avoidance of artifacts, which are caused by the lack of a defined target. The strategy has been represented by attempts to block function of secreted proteins (Garrity-Ryan et al., 2010; Grier et al., 2010; Tautz et al., 2005; Hu et al., 2013) as well as blocking the function of an essential component of the injectisome (Cowan et al., 2005). In this case, the EPEC EscN ATPase is the prime target as it is distinct from mammalian proteins (20-22\% identity to mammalian ATPases, W Swietnicki, unpublished results) essential for injectisome function (Gauthier \& Finlay, 2003; Thomas et al., 2005) and the virulence of the pathogen (Zarivach et al., 2007).

To help in search for new inhibitors of T3SS EscN ATPase, the existing structural data were examined. Analysis of the EscN ATPase active site amino acid shell within $5 \AA$ of the bound ADP ligand (PDB code: $2 \mathrm{obm}$ ) demonstrated many small differences between the mammalian systems and the bacterial ATPase. For example, comparison with bovine mitochondrial F1ATPase (PDB code: 2jiz), the closest class of structural analogs of bacterial enzyme, showed a number of small residue variations in positions 355 (Phe vs. Tyr), 185 (Thr vs Val 164), 184 (Ser vs. Thr 163), 417 (Ser vs Pro 417), 189 (Met vs. Phe418). Potential other differences could be observed if the structure of hexameric EscN were known. The differences could be exploited by random screening of compounds binding to the site in hopes that some may be specific for the EscN ATPase instead of the mammalian ATPases. The strategy is commonly used in HTS screening of large virtual libraries of small molecule compounds for novel scaffolds with potential therapeutic applications. Recently, it was used in search for $Y$. pestis YscN ATPase small molecule inhibitors (Swietnicki et al., 2011). The compounds were shown to inhibit bacterial secretion process with $\mathrm{IC}_{50}$ values in low micromolar range but the correlation with ATP hydrolysis inhibition was poor. In addition, the compounds could not block the infection process in a cell culture infection model.

In the present work on T3SS EscN ATPase from enteropathogenic E. coli, the computational HTS approach was modified to better correlate with experimental results. The modified strategy was divided into two steps. In the first step, potential hits were selected as for the YscN work and tested in a HeLa cell culture model of infection with EPEC. In the second step, the hits were expanded and optimized based on the most promising compound to increase potency and lower cellular toxicity. The best compounds were demonstrated to be competitive inhibitors of EscN ATPase with $K_{i}$ values in the lower micromolar range and to selectively block toxic effects of EPEC infection associated with secreted effectors. 
The best EscN ATPase inhibitor was also demonstrated to inhibit formation of actin clusters (pedestals), needed for entry of bacteria into cells, in a cellular model of infection with EPEC. Since the compound was non-toxic to human and bacterial cells, the present work shows a possibility to design selective T3SS inhibitors with a low potential for developing bacterial resistance. This is the first report in literature showing possibility of developing selective, non-toxic inhibitors of bacterial ATPase from pathogen's virulence system capable of blocking the key step in bacterial infection. The strategy could be used against any pathogens, specifically those showing antibiotic resistance.

\section{MATERIALS AND METHODS}

Bacterial strains, media and compounds. Enteropathogenic E. coli (Escherichia coli O127:H6 str. E2348/69) was obtained from Mr. Dereck Picard from the repository of Wellcome Trust Sanger Institute, Wellcome Trust Genome Campus, Hinxton, Cambridge CB10 1SA, UK in 2012. The strain was fully sequenced and was isolated from a clinical sample of pathogen responsible for diarrhea outbreak in UK (Iguchi et al., 2009). Bacterial protein expression strains BL21(DE3), BL21(DE3) pLys and BL21(DE3)pLysS were obtained from Merck, PL. HeLa cell line stably transfected with tetracycline repressor protein (T-REx ${ }^{\mathrm{TM}}$ HeLa) was purchased from Life Technologies, PL.

Media for bacterial expression, selection and protein production induction were purchased from Life Technologies, PL; Sigma Aldrich, PL; Carl Roth, PL and Poch S.A., PL. Small molecule compounds were purchased from Enamine (www.enamine.net), MolPort (www.molport.com), Ryan Scientific (www.ryansci.com) and Asinex (www.asinex.com). Chemical synthesis of selected compounds was performed by Enamine when needed. Stock solutions of inhibitors were prepared in DMSO to a final concentration of $10 \mathrm{mM}$. Compounds were easily soluble at room temperature and stocks were stored frozen at $-20^{\circ} \mathrm{C}$. Supplies for MUSE flow cytometer were purchased from Merck, PL. Primer synthesis and DNA sequencing were performed by Genomed, PL.

Molecular modeling and computational search. Model of EscN ATPase (a.a. 103-446) was built by homology modeling based on the structure of EscN mutant (PDB code: 2obm, a.a. 103-446, P393V mutation) using standard modeling tools from Schroedinger software suite (https://www.schrodinger.com/macromodel; Sastry et al., 2013). After refinement of the model, ligands from ZINC database, a 5.4 million subset of clean drug-like molecules, were prepared with LigPrep module (Sastry et al., 2013) and docked into the ADP binding pocket using the virtual screening workflow script of the same package with a Glide module set to default settings (Friesner et al., 2006; Halgren et al., 2004; Friesner et al., 2004). Due to the high toxicity of initial hit compounds, the active site pocket size was increased to $25 \AA$ and the requirements for hydrogen bonds between $\mathrm{ADP}$ and the EscN protein observed in the crystal structure were removed in the later stages of screening. At each stage, the top $2-10 \%$ of the hits were selected for the next round of docking. Final docking included peptide backbone adjustment with Prime and an implicit solvation model from the software suite. Estimates of binding energies were performed with Molecular Mechanics/Generalized Born Surface Area (MM/GBSA) method (VSGB 2.0 energy model) employing implicit solvation (Li et al., 2011).
The MMGSA model compares favorably with the more computationally-intensive Poisson-Boltzmann method (Hou et al., 2011a; Hou et al., 2011b; Rastelli et al., 2010).

Gene cloning, protein expression and purification. Gene escN, corresponding to a.a. 1-347 of the published EscN ATPase variant (Zarivach et al., 2007; PDB code: 2obm), was optimized for E. coli expression using synthetic biology tools and cloned into pET41.a $(+)$ vector (https://www.merckmillipore.com/PL/pl/product /pET-41a\%28\%2B\%29-DNA---Novagen,EMD_ BIO-70556?ReferrerURL=https:/ / startpage.com/do/ metasearch.pl\&bd=1\#overview) as an N-terminal fusion with 6xHis and GST tags cleavable with TEV protease. The cesT gene was also optimized and cloned into pET43.1a(+) vector (https://www.merckmillipore. $\mathrm{com} / \mathrm{PL} / \mathrm{pl} /$ product $/ \mathrm{pET}-43.1 \mathrm{a} \% 28 \% 2 \mathrm{~B} \% 29-\mathrm{DNA}---$ Novagen,EMD_BIO-70939?ReferrerURL=https:/ / startpage.com/do/metasearch.pl\&bd=1). The CesT chaperone did not have any affinity tags added and was used to facilitate folding of the GST-EscN fusion protein only. Gene optimization, synthesis and cloning were performed on a fee-for-service basis (GenScript, USA).

To co-express EscN and CesT proteins, both plasmids were co-transformed into BL21(DE3)pLysS E. coli strain. After an overnight growth of a single colony in $3 \mathrm{ml}$ of LB medium in the presence of kanamycin $(25 \mathrm{mg} /$ $\mathrm{ml}$ ) and ampicillin $(50 \mathrm{mg} / \mathrm{ml})$, cells were diluted into $30 \mathrm{ml}$ of fresh $2 \times \mathrm{YT}^{\mathrm{T}}$ medium and grown at $37^{\circ} \mathrm{C}$ for the next 2 hrs. After a transfer into $300 \mathrm{ml}$ of fresh $2 \times$ YT medium, the cells were grown to $\mathrm{OD}_{600}=0.4-0.6$ for approximately 3-4 hrs and the culture was chilled to $16^{\circ} \mathrm{C}$ in the shaker for approximately $30 \mathrm{~min}$. The protein expression was induced with $0.4 \mathrm{mM}$ IPTG and the cells were shaken at $250 \mathrm{rpm}$ in baffled flasks overnight (10-12 hrs). After harvesting bacteria by centrifugation, the cell paste was stored at $-80^{\circ} \mathrm{C}$ for further processing.

To purify recombinant EscN protein, cell paste from $2 \mathrm{~L}$ culture was thawed on ice, resuspended in $100 \mathrm{ml}$ of cell lysis buffer $(1 \times$ Tris buffered saline (TBS) with $10 \%$ glycerol) supplemented with Complete protease inhibitor cocktail (Merck, PL), disrupted in French press, centrifuged at $20000 \times g$ to remove debris, and the supernatant was loaded onto $10 \mathrm{~mL}$ of GST-cellulose bed (Carl Roth, PL). After overnight incubation, the resin was washed $3 \mathrm{x}$ with the buffer, and the protein was eluted with 5 column volumes (CV) of $10 \mathrm{mM}$ reduced glutathione in 1x TBS supplemented with 10\% glycerol. The eluted fractions were dialyzed against $1 \mathrm{x}$ TBS with $10 \mathrm{mM}$ imidazole and incubated with $10 \mathrm{~mL}$ of Co-agarose bed (Sigma Aldrich, PL) in the presence of $10 \mathrm{mM}$ 2-mercaptoethanol at $4^{\circ} \mathrm{C}$ for $1 \mathrm{hr}$. The resin was loaded onto a glass column, washed $3 \mathrm{x}$ with $5 \mathrm{CV}$ of the binding buffer and the protein was eluted with stepwise imidazole concentration under gravity flow. Fractions from 100 and $200 \mathrm{mM}$ imidazole elution were retained after SDS-PAGE confirmation. Typically, the buffer was exchanged into $1 \times$ TBS, $20 \%$ glycerol, $2 \mathrm{mM}$ DTT in Amicon Ultra-4 concentrators (Merck, PL) and the protein was concentrated to 4-6 $\mathrm{mg} / \mathrm{ml}$. Protein concentration was determined based on $\mathrm{OD}_{280}$ values and corrected on amino acid content using ProtParam web server (http:// web.expasy.org/protparam/). For storage, protein was aliquoted into $100-200 \mathrm{ml}$ volumes and stored at $-80^{\circ} \mathrm{C}$.

Attempts to remove the GST tag were not successful as the protein degraded under protease cleavage conditions. Therefore, the fusion construct was used in all subsequent experiments.

EspG protein production was performed commercially on a fee-for-service basis (BLIRT, PL). The espG1 gene 
coding for protein fragment a.a. 44-398 with a cleavable 6xHis N-terminal sequence was optimized for E. coli expression and made synthetically (GeneArt, DE) based on the published structure (Germane \& Spiller, 2011; PDB code: $3 q 1 \mathrm{c})$. The gene was cloned into pGEX-4T vector between BamHI and XhoI sites, confirmed by DNA sequencing and transformed into BL21(DE3) RIL cells for protein production. For protein expression, cells were grown in a Terrific Broth (TB) medium and protein expression was induced with $0.5 \mathrm{mM}$ IPTG at $25^{\circ} \mathrm{C}$. After harvesting the cells, the protein was extracted using standard purification protocols designed for GST-fusion constructs. The affinity-purified fusion was digested with recombinant TEV protease at $4^{\circ} \mathrm{C}$ overnight and the fusion part was removed by two affinity steps, GST-agarose and Ni-NTA agarose. The final protein was homogenous on SDS-PAGE and eluted as a single peak $(80 \%+$ purity) on a Superdex 75 5/150 GL (GE Healthcare) column.

Protein was concentrated to $1 \mathrm{mg} / \mathrm{ml}$ in $50 \mathrm{mM}$ Tris, $\mathrm{pH}=8.0,150 \mathrm{mM} \mathrm{NaCl}, 20 \%$ glycerol and stored in $100 \mathrm{ml}$ aliquots at $-80^{\circ} \mathrm{C}$. Protein concentration was determined with Bradford's assay.

$\boldsymbol{E} \boldsymbol{s} \boldsymbol{N}$ gene knockout. The kanamycin resistance marker $\left(\operatorname{Kan}^{\mathrm{R}}\right)$ was amplified from pET28a plasmid and fused with sequences coding the esc $\mathrm{N}$ gene using listed primers (Table S1, Supplemental Information at www. actabp.pl) and strategy outlined in Supplemental Information (Fig. S1 at www.actabp.pl). The procedure was based on variation of a published strategy (Gust et al., 2003). Briefly, three parts were made in parallel: the left homology arm (H1) using primers 1 and 2, the kanamycin resistance cassette (kanamycin resistance) using primers 3 and 4, and the right homology arm (H2) using primers 5 and 6 . The parts were fused stepwise using overlap extension PCR and the final product was amplified by PCR and gel purified. The final PCR product was flanked by 1000 bp regions of homology to the esc $\mathrm{N}$ gene on each side. After amplification, the final PCR product was digested with DpnI enzyme, re-purified by gel agarose and resuspended in elution buffer $(10 \mathrm{mM}$ Tris, $\mathrm{pH}$ 8.0). For the later transformation with linear DNA, EPEC cells carrying a helper pIJ790 plasmid (Gust et al., 2003) carrying a $\lambda \operatorname{Gam}(\gamma)$ gene expressing exonuclease $\mathrm{V}$ of the $\operatorname{rec} B C D$ system inhibitor under the control of araC promoter were grown in $5 \mathrm{ml} \mathrm{SOB}$ medium with chloramphenicol $(30 \mu \mathrm{g} / \mathrm{ml})$ at $30^{\circ} \mathrm{C}$ to an $\mathrm{OD}_{600} \sim 0.3$. At this point, a $10 \%$ L-arabinose solution was added to a final concentration of $0.4 \%$ and the cells were incubated at $37^{\circ} \mathrm{C}$ for $1 \mathrm{hr}$. This step induced inhibitor expression allowing for a more efficient recombination with the linear DNA. The cells were made electrocompetent by concentrating 100 -fold and washing $3 \mathrm{x}$ with ice-cold 10\% glycerol solution. Electrocompetent cells were transformed with product by electroporation and colonies were selected on kanamycin $(30 \mu \mathrm{g} / \mathrm{ml})$ using standard procedures. The plates were incubated at $37^{\circ} \mathrm{C}$ overnight, the colonies purified once non-selectively at $37^{\circ} \mathrm{C}$ and then tested for chloramphenicol sensitivity to verify loss of the helper plasmid. Selected colonies exhibiting chloramphenicol resistance were colony purified once at $42^{\circ} \mathrm{C}$ and similarly tested for the loss of helper plasmid. The final EPEC mutant was kanamycin resistant and chloramphenicol sensitive.

Enzyme activity measurements. Activity measurements of the EscN protein were performed using EnzCheck kit (Life Technologies, PL). Measurements were performed at R.T. according to the manufacturer's instructions using the reaction buffer containing $20 \mathrm{mM}$
Tris, $\mathrm{pH}=8.5,150 \mathrm{mM} \mathrm{NaCl}$ and $2 \mathrm{mM} \mathrm{MgCl}_{2}$. Each enzyme preparation was calibrated with the EnzCheck kit to ensure linearity of reaction progress versus time and the enzyme concentration. Data analysis and graphing was performed with KaleidaGraph (Synergy Software) program.

To measure steady state kinetics, data were fitted to a steady state kinetics equation using a Lineweaver-Burke transformation (Lineweaver \& Burk, 1934). Inhibition type and kinetics were performed using a steady state kinetics model. Briefly, a $10 \mathrm{mM}$ stock concentration of inhibitor in DMSO was added to the reaction buffer to give a final concentration of $10-200 \mu \mathrm{M}$ and was incubated at R.T. in the presence of recombinant EscN ATPase for $10 \mathrm{~min}$. After that time, ATP was added and the reaction progress was monitored by following $\mathrm{OD}_{360}$ for up to $30 \mathrm{~min}$.

To exclude interference of DMSO and inhibitors with the assay conditions, additional tests were performed. DMSO interference with EscN activity was observed at $5 \%$ DMSO concentration but not at the $2 \%$ maximum concentration used in the tests. Interference with the phosphorylase $b$ activity by inhibitors was performed by comparing kinetics of phosphate addition to MESG using phosphate standard provided with the kit. For compounds WEN05-03 and WEN04-34, there was no observed difference in kinetics of phosphorylase $b$ activity at $100 \mu \mathrm{M}$ inhibitor concentration using the assay conditions described above.

To determine the type of inhibition, the data were analyzed according to Dixon plots (Dixon, 1953) using $0.6 \mathrm{mM}$ and $1.2 \mathrm{mM}$ ATP concentrations. Data for the lower concentrations of substrate had low signal-to-noise ratios and were not used in measurements.

EspG antibody production. New England white rabbit was immunized intradermally with purified EspG1 suspended in a Complete Freund's Adjuvant (CFA) using a checkerboard technique: 4 squares $10 \times 10 \mathrm{~cm}$, each square having 25 injections of $50 \mathrm{ml}$ antigen in emulsion with injections separated by $2 \mathrm{~cm}$. The procedure was repeated every 4 weeks for a total of 3 times with the CFA replaced by Incomplete Freund's Adjuvant (IFA) in all subsequent immunizations. Antibody titer was determined 2 weeks post-injection from a serum sample from blood collected from ear artery by ELISA using a MaxiSorp plate coated with EspG and an anti-rabbit secondary antibody conjugated with HRP. The final antibody titer was 1:320000. At this stage, the rabbit was exsanguinated, serum isolated and heat-inactivated at $56^{\circ} \mathrm{C}$ for $30 \mathrm{~min}$. The inactivated serum was aliquoted into $1 \mathrm{ml}$ aliquots and stored at $-80^{\circ} \mathrm{C}$ for further experiments. Due to the extremely high titer and the instability of the unpurified serum, further purification of the serum was not undertaken.

HeLa cell culture infection and effectors secretion inhibition. Approximately $3 \times 10^{5} \mathrm{HeLa}$ cells/well in a 24-well plate were infected with overnight cultures of wild type (wt) EPEC, BL21(DE3) and DescN mutant of EPEC at the MOI of 20:1. For time point analysis of infection, the cells were fixed with $5 \%$ paraformaldehyde (PFA) and stained for DNA with DAPI and actin with phalloidin-Atto 488 (Sigma Aldrich) each hour for up to 5 hrs using standard protocols. Stained cells were observed on an Axio Vert.A1 (Zeiss) inverted fluorescent microscope. Internalized bacteria could be easily visualized after 2 hrs and after 5 hrs the HeLa cell culture was more than $90 \%$ destroyed.

To assess blockage of effector secretion by inhibitors, gentamycin protection assay was used (Vaudaux \& Wald- 
vogel, 1979). Approximately $3 \times 10^{5}$ cells/well in a 6 -well plate were grown overnight, inhibitors were added to the medium $(100 \mu \mathrm{M}$ total), and the cells were infected with wt EPEC, BL21 (DE3) and DescN mutant of EPEC at MOI of 1:100 for 2 hrs to allow for internalization. Medium was removed, replaced with a fresh one and the extracellular bacteria were killed by incubation with $100 \mu \mathrm{M}$ gentamycin for $1 \mathrm{hr}$, cells were washed $2 \mathrm{x}$ with $1 \mathrm{xPBS}$, and either prepared for confocal microscopy by staining for actin and DNA or processed further for Western blotting analysis. For the latter, the cells were harvested by centrifugation, lysed with $300 \mu \mathrm{L}$ of $1 \%$ Triton X-100 and the proteins were acetone-precipitated $\left(4 \times\right.$ volume, $\left.-80^{\circ} \mathrm{C}, 48 \mathrm{hrs}\right)$ and analyzed by SDS-PAGE. Western blots were probed with inactivated anti-EspG1 rabbit polyclonal serum (1:10000), secondary goat anti-rabbit HRP-conjugated polyclonal antibody and bands were detected with Pico West chemiluminescence kit on a CL-X Posure film using manufacturer's recommendations. Due to the low levels of EspG protein present, the exposure time was increased up to $10 \mathrm{~min}$ to detect sub-nanogram quantities of protein. For the same reason, the MOI was increased to 100:1 and the cells were collected from 6-well plates instead of the usual 24-well plates.

MTT toxicity tests. Approximately $1 \times 10^{4}$ cells/well were grown in 96-well plates in EMEM supplemented with $10 \%$ fetal bovine serum and $2 \mathrm{mM}$ L-glutamine in an incubator under $5 \% \mathrm{CO}_{2}$ and $95 \%$ humidity at $37^{\circ} \mathrm{C}$ overnight. The next day, compounds were added to wells at a given concentration and incubated for an additional time. Time points were taken at 2, 4 and 24 hrs after addition.

To measure toxicity, $50 \mathrm{ml}$ of the $0.5 \mathrm{mg} / \mathrm{ml} \mathrm{MTT}$ stock solution in medium without FBS was added to each well. Cells were incubated for additional $4 \mathrm{hrs}$ at $37^{\circ} \mathrm{C}$, medium was removed and $50 \mathrm{ml}$ of DMSO was added. After a 10 min incubation on a shaker, the absorbance at $570 \mathrm{~nm}$ was measured and the data were processed using KaleidaGraph program.

Live/Dead tests. For Live/Dead (Life Technologies) double staining, cells were seeded at a density of $1 \times 10^{4}$ cells/well onto 96-well plate and grown in MEM supplemented with $10 \% \mathrm{FBS}$ and amino acids in an incubator maintained at $37^{\circ} \mathrm{C}$ and $5 \% \mathrm{CO}_{2}$. Determination of viable/dead cells was performed according to manufacturer's instructions.

Flow cytometry. Flow cytometry was used to determine apoptosis and cell viability. The measurements were performed on a MUSE Cell Analyzer system (Mer$\mathrm{ck}$ ) using standard kits and adjustments recommended by the manufacturer. Before each test, the system was calibrated with a System Check kit (Merck).

Cell viability. Cell viability was determined with MUSE Count \& Viability kit (Merck). Approximately $1 \times 10^{5}$ cells/well were grown on 24 -well plates (SciencePlast, PL) in EMEM supplemented with 10\% FBS and $2 \mathrm{mM}$ L-glutamine in an incubator maintained at $37^{\circ} \mathrm{C}$ and $5 \% \mathrm{CO}_{2}$. The next day, inhibitors were added to the medium to a predetermined final concentration and the cells were grown for additional 24 hrs. Methanol treatment for a short time was used as a positive control and medium alone as a negative control. Cell viability was determined using recommended manufacturer's procedures. Data were processed with KaleidaGraph program.

Cell apoptosis, mitochondrial potential interference and cell cycle analysis were performed in a similar way using recommended procedures and kits from Merck
(MUSE Annexin V \& Dead Cell Assay, MultiCaspase Assay, MitoPotential Assay and Cell Cycle Assay kits).

Confocal microscopy analysis of inhibition of pedestal formation in infected HeLa cell cultures. Twenty four-well plate cultures of HeLa cells were treated with inhibitors as described before, stained with DAPI and phalloidin-Atto 488 and imaged on a Cell Observer Spinning Disk confocal microscope(Zeiss) equipped with EMCCD Andor iXon3 885 camera. The imaging was performed sequentially using $405 \mathrm{~nm}$ and $488 \mathrm{~nm}$ laser lines with quadruple dichroic mirror $405+488+561+640$ and $450 / 50$ and 520/35 emission filters. From each experimental condition, three to seven random areas were chosen and Z stacks were taken with a $2 \mu \mathrm{m}$ step size using $10-20 \times$ dry objectives $(0.667 \mu \mathrm{m}$ and $0.333 \mu \mathrm{m}$ per pixel, respectively). The same acquisition settings were applied to all conditions. To quantify pedestal formation, maximum intensity projections from $Z$ stacks were created and phalloidin-Atto 488 channel was segmented to obtain two masks: cell area mask (CAM, fluorescence intensity threshold was typically 15-20 in 8-bit images) and actin clusters mask (ACM, fluorescence intensity threshold was typically 100-126). Based on the ACM image actin clusters with size between $0.9-28 \mu \mathrm{m}^{2}$ and circularity between $0.5-1$ were counted using ImageJ's (http://imagej.nih.gov/ij/) Analyze Particles function. Total actin area per field of view, shown by CAM, was used to normalize data as the cell density differed slightly between imaged regions. Thus, the final actin cluster number in a field of view was a product of the normalization factor (field of view area/CAM area in the analyzed image) and the number of actin clusters per image. Bars in the graph are means from three to seven fields of view \pm standard deviation. The inhibition of pedestal formation was statistically evaluated with a one-way ANOVA test.

\section{RESULTS}

\section{Enzyme expression and characterization}

The choice of construct for protein expression and characterization was dictated by the stability of purified protein. Therefore, the construct lacked the N-terminal domain normally involved in hexamerization/protein aggregation and contained an additional mutation to improve stability of the purified protein. Recombinant EscN ATPase was expressed as a fusion with a cleavable GST tag at the N-terminus (Fig. 1).

After a two-step affinity purification, first on a glutathione Sepharose and then on a Ni-agarose column, the enzyme was at least $90 \%$ pure by SDS-PAGE (Fig. 2B). The enzyme was stable when stored at $-80^{\circ} \mathrm{C}$ and the activity could be measured for at least 6 months after preparation. Typically, measurement would require a change of $0.01-0.02 \mathrm{OD}_{360}$ or higher in the signal under experimental conditions to have reliable data.

Attempts to remove the GST tag led to enzyme degradation. Therefore, the tag was left on the protein and the GST-fusion construct was used in all subsequent experiments.

Enzymatic activity of the protein was measured using a coupled ATP hydrolysis assay. The measured $V_{\mathrm{m}}$ and $K_{\mathrm{m}}$ values (Fig. 2, left panel) were $0.24 \pm 0.01$ (S.D., $\mathrm{n}=2) \quad \mathrm{nmol} \times \mathrm{min}^{-1} \times \mathrm{mg}^{-1}$ and $0.47 \pm 0.02$ (S.D., $\mathrm{n}=2$ ) $\mathrm{mM}$, respectively. The values were in the broad range reported for other enzymes (Blaylock et al., 2006;_ENREF_7 Swietnicki et al., 2011; Stone et al., 2008; Andrade et al., 2007). Measured $k_{\text {cat }}$ and $V_{\max } / K_{\mathrm{m}}$ values were 
CesT a.a.1-156

\begin{tabular}{l|l|l} 
6xHis & GST & TEV
\end{tabular}

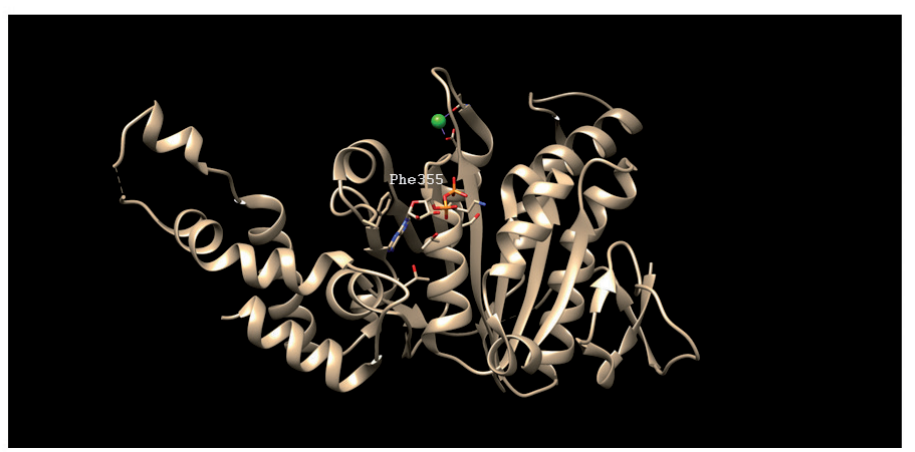

Figure 1. Protein template constructs used in the current work.

Full length a.a. 1-156 chaperone CesT (Panel A) and ATPase fragment a.a. 103-392 (Panel B) and the structure of EscN cloned fragment (Panel C) based on the published data (PDB code: 2obm). The bound ADP ligand (Panel C) is shown for orientation purposes. GST-glutathione transferase, TEV-tobacco etch virus $3 \mathrm{C}$ protease cleavage site, $6 x \mathrm{His}-\mathrm{HHHHH}$ peptide. ADP ligand colors: red-OH/O- groups, blue- $\mathrm{N}$ atoms, grey-carbon atoms. The $\mathrm{Ca}^{+2}$ ion from the original structure is shown as a green sphere. Residue Phe355 is shown and labeled for orientation purposes.

$0.289 \pm 0.12$ (S.D., $\mathrm{n}=2$ ) $\mathrm{s}^{-1}$ and $0.48 \pm 0.02 \times 10^{-3}$ (S.D., $\mathrm{n}=2) \mathrm{M} / \mathrm{s}$, respectively, which would classify the enzyme as slow. In our work, the initial velocity seemed to decrease with substrate concentration above $4 \mathrm{mM}$ [ATP]. Therefore, the reported $K_{\mathrm{m}}$ and $V_{\max }$ values were measured below $[\mathrm{ATP}]=4 \mathrm{mM}$ and should be treated as the apparent parameters.

The enzyme showed a weak cooperativity, similar to the previous work reported for the a.a.94-419 YscNMBP fusion protein (Swietnicki et al., 2011) and the full length EscN protein (Andrade et al., 2007). The property may be explained by oligomerization of ATPase in the presence of ATP (Blaylock et al., 2006; Andrade et al., 2007). The value of Hill's coefficient determined in the present work would suggest that the enzyme may work as a dimer.

\section{A}

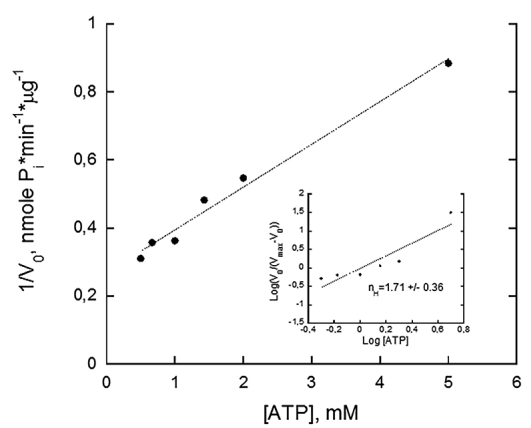

B

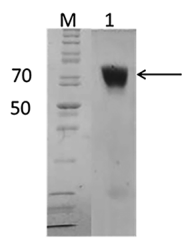

Figure 2. Characterization of recombinant GST-EscN fusion protein.

(Panel A) Lineweaver-Burke plot of EscN enzymatic activity. Inset: Determination of cooperativity of recombinant enzyme. Activity of recombinant EscN enzyme was measured versus its natural substrate ATP at R.T. as described under Materials and Methods. Enzyme concentration was $7.1 \mu \mathrm{M}$. (Panel B) SDS-PAGE analysis of purified enzyme. Lanes: $M$, molecular weight markers; 1, purified recombinant protein. Total protein load per lane was $2.5 \mathrm{mg}$. Numbers on the left correspond to molecular weight standard size in $\mathrm{kDa}$.
Inclusion of the data for $0.3 \mathrm{mM}$ ATP concentration changed the $V_{\max }$ value to 0.19 \pm 0.01 (S.D., $\mathrm{n}=2$ ) nmol $\times \mathrm{min}^{-1} \times \mathrm{mg}^{-1}$ and $K_{\mathrm{m}}$ to $0.34 \pm 0.02$ (S.D., $\mathrm{n}=2$ ) $\mathrm{mM}$. The step changed the values by approximately $20 \%$ but increased the error of Hill's coefficient determination significantly. Therefore, the data were not included in the calculation of kinetic parameters.

\section{Compound screening of ZINC database and initial hit verification}

The rationale for potential selection of inhibitors was based on analysis of active sites of known ATPases, in particular the bacterial T3SS EscN mutant (PDB code: 2obm) and the bovine F0F1 ATP synthase (PDB code: 2jiz), and the residues interacting with the bound ligand. While the key catalytic residues were identical, overlay of active sites of EscN and other mammalian enzymes identified differences in residues within $5 \AA$ of the bound ligand. A comparative analysis of bovine mitochondrial synthase, the closest structural analog of EscN, and the bacterial enzyme was described in the introduction. A direct strategy to use ATP/ADP as a template to construct a selective inhibitor exploiting the small differences was discarded due to the potential side effects. Instead, the whole active site was used as a search template in hopes of identifying
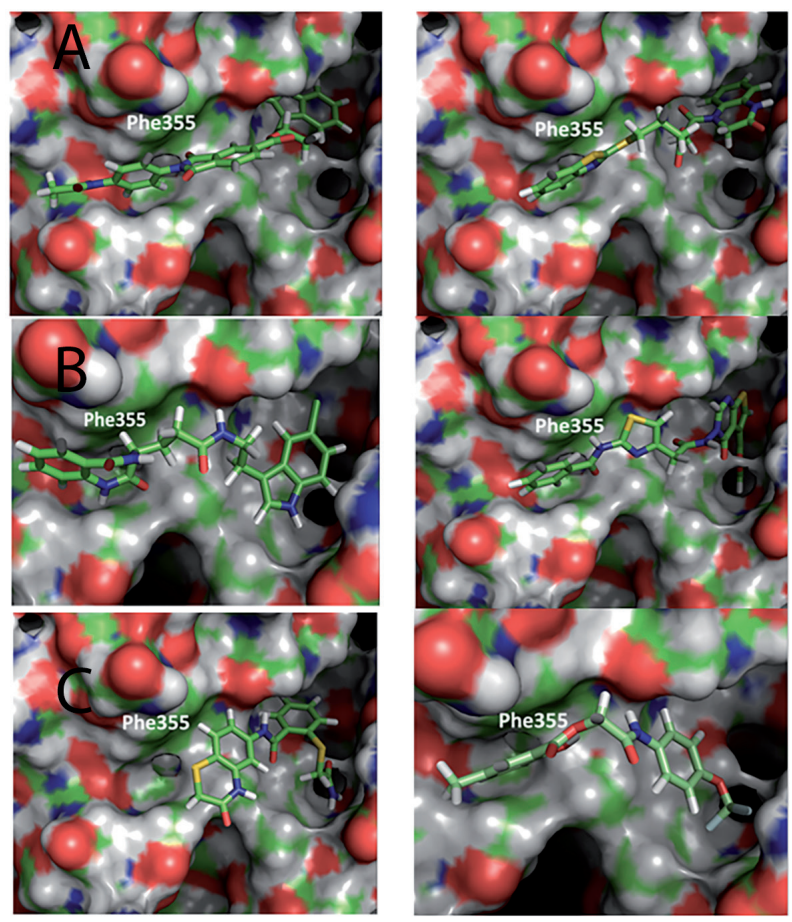

Figure 3. Best poses of selected top EscN ATPase inhibitors docked into the active site of enzyme.

Poses are from the final computational screen of compounds binding in the active site of the enzyme as described under Materials and Methods. (Panel A) left to right: Inh9, Inh26; (Panel B) left to right: Inh36, Inh42; (Panel C) left to right: Inh54, Inh69. Position of Phe355 residue from the EscN is also marked for orientation. Surface color: red, positively charged; blue, negatively charged; green, neutral; grey, polar. 
Table 1. List of the most active compounds in the ATP hydrolysis inhibition test.

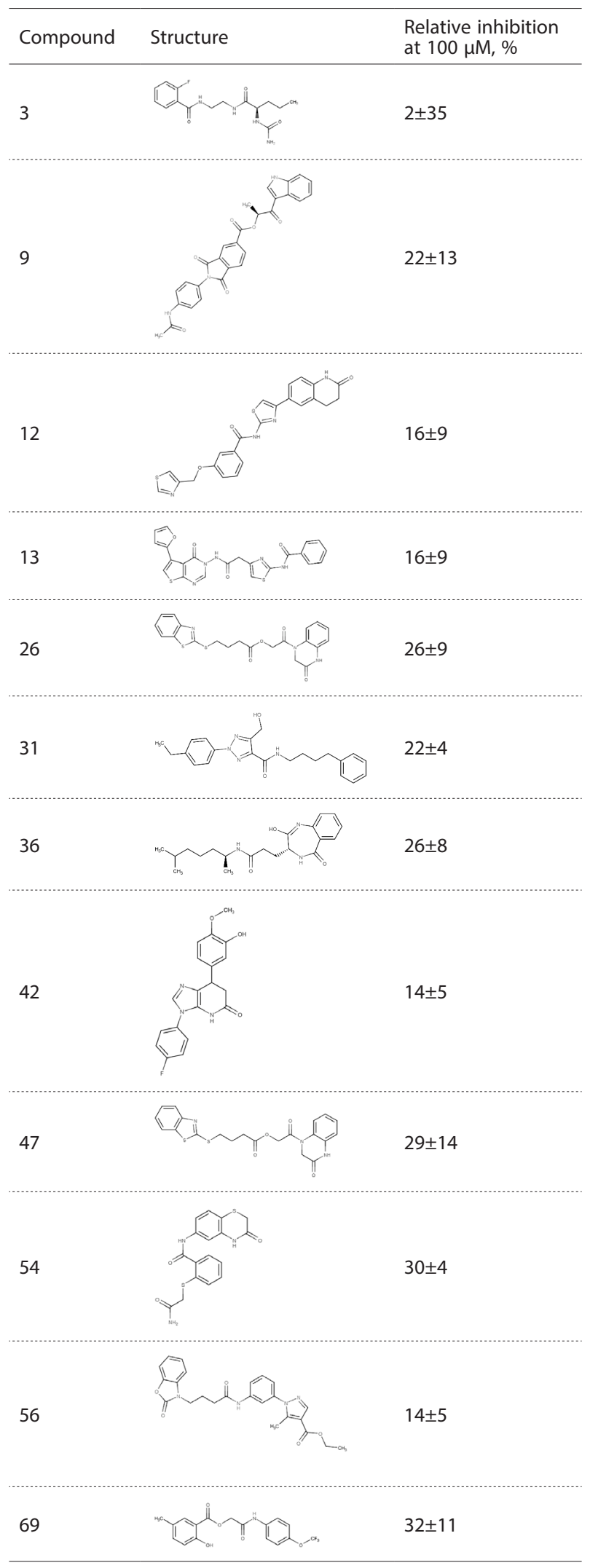

compounds exploiting many unique differences simultaneously and potentially identifying a selective inhibitor from a large scale screening of virtual libraries.
Computational screen of ZINC database identified over 3000 top scoring compounds based on the binding energy. In the initial stages of screening, compounds selected using default program parameters were tested for cellular toxicity and found to be unacceptable. Therefore, the search parameters were modified to decrease the toxicity and increase the pool of compounds after the final selection. In total, the top 70 compounds were purchased for experimental testing. The compounds were tested for inhibition of ATP hydrolysis by the recombinant EscN protein. The first screen, performed at $100 \mu \mathrm{M}$ inhibitor concentration, identified $12 \mathrm{com}-$ pounds with the inhibition above 14\% (Fig. 3, Table 1). The inhibition was weak at this stage and attempts to determine the inhibition constants were abandoned.

ATP hydrolysis test was performed with recombinant EscN protein using a coupled assay as described under Materials and Methods. Rate of hydrolysis for the EscN ATPase without inhibitors was used as a reference value for the inhibition by compounds. Relative inhibition values are mean \pm S.D. $(n=3)$.

For selected compounds, the weak inhibition observed at this stage could have been explained by poor solubility. Compounds 12, 31 and 69 formed crystals at $100 \mu \mathrm{M}$ concentration when tested in a cell culture (data not shown). Compound 26 precipitated at concentrations above $100 \mu \mathrm{M}$ which precluded determination of $K_{\mathrm{i}}$ values in kinetic studies. This fact might have caused errors during measurements.

\section{Toxicity screening of confirmed EscN ATPase inhibitors}

Analyzed compounds were next examined for toxicity in a series of biological tests using HeLa cell in vitro cultures. Overall, the viability of cells in the presence of all compounds was very good (Fig. 4A).

The Live/Dead test measures overall metabolism by quantifying conversion of a calcein derivative into a fluorescent compound by viable cells and penetration of nuclei of only the dead cells by propidium iodide. For Compound 13, the result was false positive because the flow cytometer counted only the surviving cells which biased assay results. Therefore, the toxicity was confirmed by microscopy observations for all compounds. In the presence of $100 \mu \mathrm{M}$ Compound 13, most of the cells were disintegrated and could not be observed (data not shown). Based on this data, it was concluded that Compound 13 causes cellular disintegration (microscopy) over time but the surviving cells retain ability to carry out metabolism (flow cytometry).

Analysis of annexin V binding as a measure of apoptosis showed that two compounds increased the frequency of apoptosis in cells (Fig. 4B). Compound 13, which was highly toxic in the optical microscopy test, led to the mostly late apoptosis in $40 \%$ of cell population, while Compound 54 stimulated mostly an early phase apoptosis in $20 \%$ of cells with a late apoptosis present in less than $10 \%$ of the cell population. The data were corroborated additionally by morphological analysis and Live/Dead tests under the light microscope (data not shown). Compounds 54 and 42 did not cause cell death (less than $0.4 \%$ ), while Compound 26 caused only $0.8 \%$ cellular death as measured by propidium iodide incorporation. Data for the rest of compounds varied between $50-90 \%$ for the cell death rate in a MT'T test. The level of cellular metabolism for the three compounds as measured by calcein-AM hydrolysis was also on the level measured for the control untreated HeLa cells (data not shown). Finally, after a general MT'T-based cell toxicity 

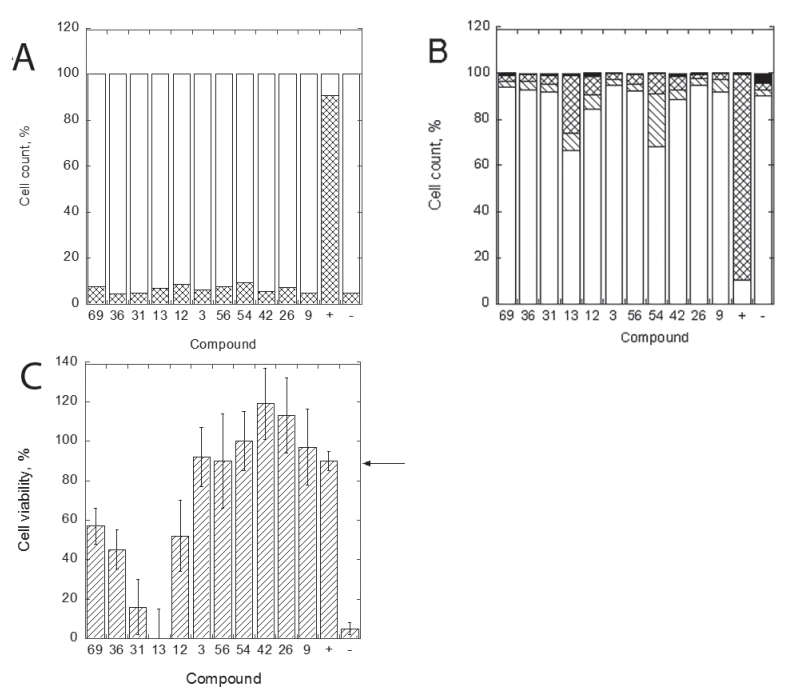

Figure 4. Toxicity screens of selected compounds in HeLa cell cultures.

(Panel A) Cell viability screen by flow cytometry. Bars: white, live cells; crosshatched, dead cells. (Panel B) Apoptosis screen for Annexin $\mathrm{V}$ binding by flow cytometry. Bars: white, live cells; hatched, early apoptosis; crosshatched, late apoptosis; black, dead cells. (Panel C) MTT screen of whole cell cultures. Reported values are averages of at least two independent experiments and error bars reflect the range between the minimum and maximum values. Arrow on the right shows the cutoff for compounds selected for further screening. Compound concentration was $100 \mu \mathrm{M}$. Measurements were performed as described under Materials and Methods section. Time points shown are for 24 hrs post-addition.
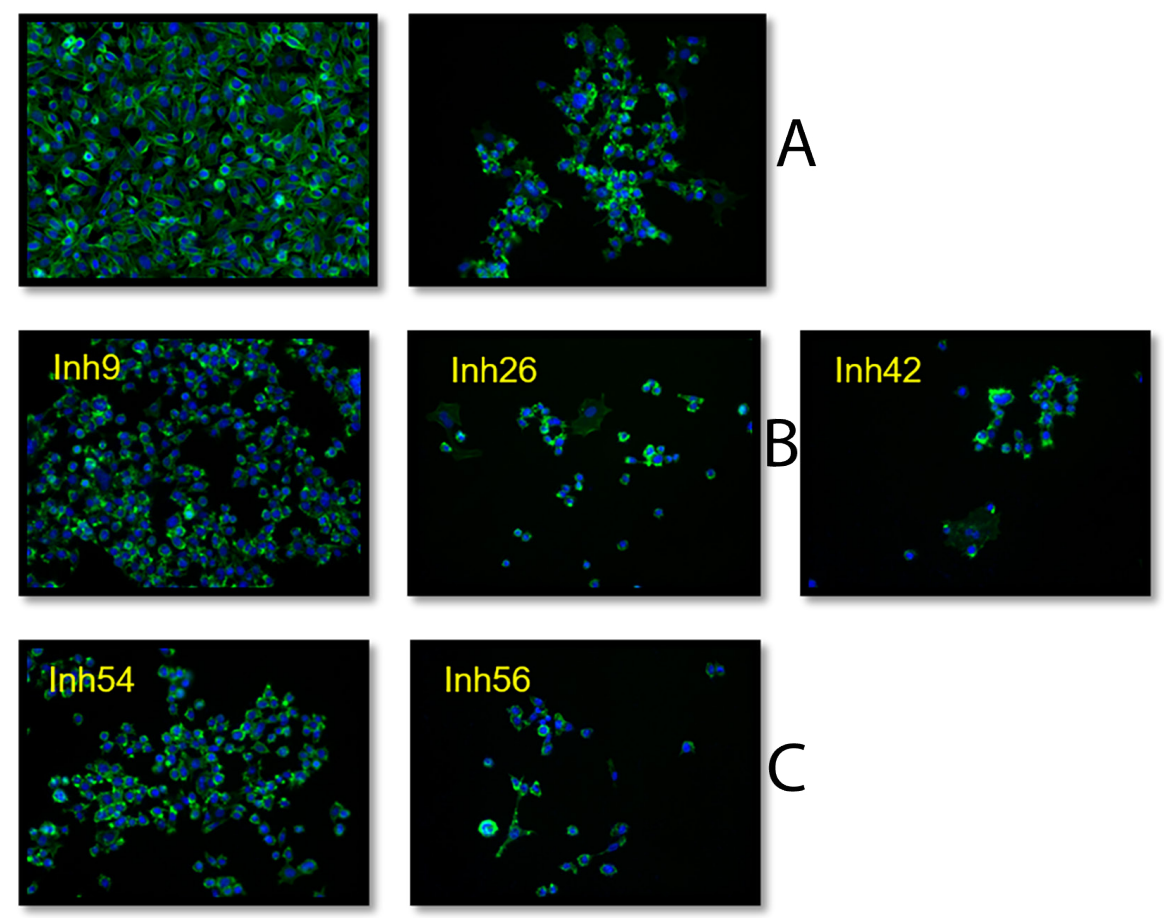

Figure 5. Compound 9 and Compound 54 partially prevent HeLa cell destruction by enteropathogenic E. coli.

HeLa cells were infected with enteropathogenic E. coli at MOI 20:1 with or without inhibitor and left in an incubator for 4.5 hrs. After that time, cells were fixed with paraformaldehyde, stained for actin (green) and DNA (blue) and imaged as described under Materials and Methods. (Panel A) left column - uninfected cells at 0 hrs, right column - infected cells after 4.5 hrs. (Panel B and Panel C) HeLa cells after 4,5 hrs incubation with pathogen in the presence of $100 \mu \mathrm{M}$ inhibitors. Inh9-Compound 9, Inh26-Compound 26, Inh42-Compound 42, Inh54-Compound 54 and Inh56Compound 56 . screen, only five compounds (9, 26, 42, 54 and 56) were selected for further characterization (Fig. 4C).

The flow cytometry tests show data for surviving cells while the MT'T test indicates values based on the metabof all surviving cells. While the former may give false positive results as described for the Compound 13 before, the latter would avoid such artifacts due the the dye.

\section{Evaluation of T3SS blockage based on interference with spG secretion}

In the next step, selected compounds were evaluated for blockage of EPEC infection in a HeLa cell culture The microscopic analysis of infection progress at the MOI of 20:1 showed that at around 2 hrs post infection, the cells were mostly preserved but the bacteriainduced actin-rich pedestals were already present and the pathogen was able to destroy the cell culture at the $5 \mathrm{hr}$ point (Fig. S2, Supplemental Information at www. actabp.pl). Upon treatment with the tested compounds, only Compound 9 and 54 were effective in blocking cell destruction by pathogen after $4.5 \mathrm{hrs}$, time sufficient to destroy most of the HeLa cells (Fig. 5). The three other compounds: 26, 42 and 56, were ineffective at the concentration used in the assay $(100 \mu \mathrm{M})$.

The pathogen requires an active EscN ATPase to the ATP hydrolysis would abolish the process. The effector EspG is secreted in very small amounts into the mammalian cells (Mills et al., 2008) and was used as a marker of secretion process. At $100 \mu \mathrm{M}$ concentration, only two compounds, Compound 54 and Compound 26, were able to block the secretion significantly (Fig. 6). Densitometric analysis of Western blot experiment showed that the Compound 54 reduced EspG secretion by $60 \%$ while Compound 26 abolished the secretion completely (Fig. 6).

Importantly, the compounds did not inhibit bacterial cell growth (Fig. 7; time of effector secretion inhibition measurement marked with an arrow) at the $2 \mathrm{hrs}$ time point used for effector secretion inhibition measurements so the observed inhibition of EspG secretion by Compounds 54 and 26 was not caused by bacteriostatic effect of the studied compounds $\left(\mathrm{OD}_{600}=0.19 \pm 0.01\right.$, control vs $\mathrm{OD}_{600}=0.20 \pm 0.01$, Compound 26, and $\mathrm{OD}_{600}=0.18 \pm 0.01, \quad$ Compound 54). Compound 9 showed a small stimulation of bacterial growth at the $2 \mathrm{hrs}$ time point $(\mathrm{OD} 600=0.22 \pm 0.01)$ and a noticeable growth inhibition at the $5 \mathrm{hrs}$ time point (OD $600=0.80 \pm 0.02$ control vs $\mathrm{OD} 600=0.60 \pm 0.05)$ which could possibly explain pro- 


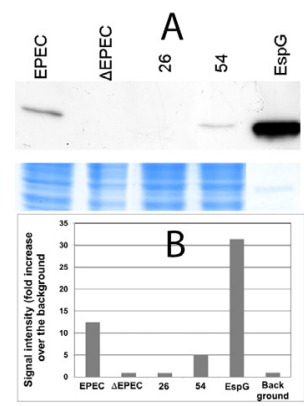

Figure 6. Compounds 54 and 26 can block EspG1 secretion by enteropathogenic $E$. coli in HeLa cells.

HeLa cells were infected with enteropathogenic E. coli at MOI 100:1 for 2 hrs and the secreted EspG1 was detected as described under Materials and Methods. (Panel A) Western blot, bottom - Simply Blue (Life Technologies) staining of the corresponding SDS-PAGE gel section. Lanes: EPEC, wt enteropathogenic E. coli; $\triangle E P E C, \triangle$ esCN mutant of EPEC; 26 , EPEC $+100 \mu \mathrm{M}$ Compound 26; 54, EPEC + $100 \mu \mathrm{M}$ Compound 54; EspG, $1 \mathrm{ng}$ of recombinant EspG1. Data are representative of at least 3 experiments. (Panel B) Densitometric analysis of representative Western blot results. The analysis was performed with ImageJ software and corrected for the background.
A

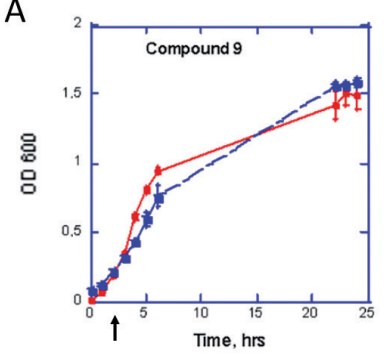

B

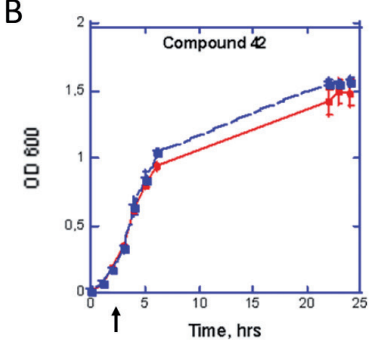

C

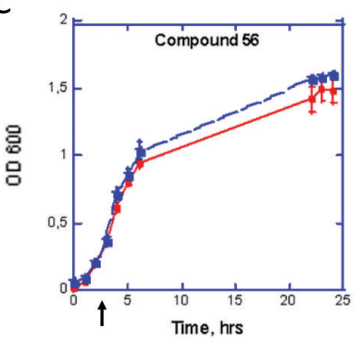

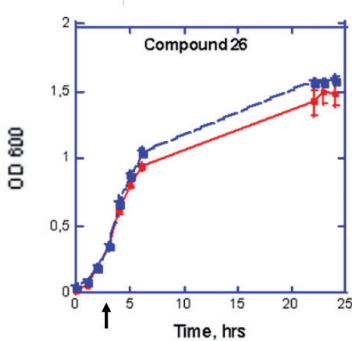

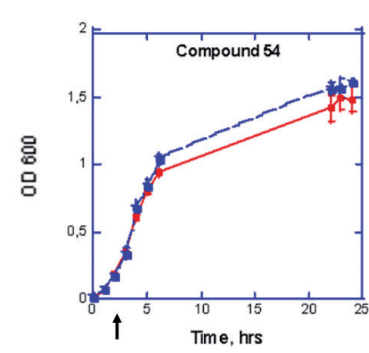

tection in the EPEC infection assay at the 4.5 hrs time point (Fig. 5).

Analysis of the full curves showed that all compounds, except Compound 9, affected growth rate of bacteria $(p<0.05)$ when the data were considered for up $24 \mathrm{hrs}$. However, analysis of data for the selected $2 \mathrm{hrs}$ time point showed that differences at this time point were below $10 \%$. Statistically, there were not enough data points up to $3 \mathrm{hrs}$ to form a valid hypothesis. Therefore, the compounds did not inhibit bacterial growth at the 2 hrs time point more than $10 \%$ but showed statistically valid influence (growth stimulation) when the time was extended up to $24 \mathrm{hrs}$. The phenomenon could be connected to compound stability and metabolic availability as all inhibitors contain a labile ester bond.

\section{Evaluation of selected initial hits in protection of cell destruction by enteropathogenic $E$. coli}

Biological experimental data together with the analysis of chemical structures of all five compounds suggested that only Compound 54 would be most suitable for potential drug development. The other candidate was Compound 26 which blocked EspG secretion but it did not offer any protection in the HeLa infection tests (Fig. 5).

Structural analysis of Compounds 26 and 54 demonstrated that Compound 26 is relatively long and very flexible, making it difficult to optimize due to potential off-target hits by flexible parts. Compound 54 , on the other hand, is very bulky and would not have these problems. Also, its propensity to induce apoptosis could be a side effect removable after further optimization.

\section{Virtual analysis of predicted binding poses in the EscN ATPase active site model}

Virtual analysis of binding modes in the $\mathrm{EscN}$ pocket (Fig. 3) suggested that the part containing the ortho-substituted benzamide fit very well in the pocket in contrast to the benzothiazine-containing part which did not fit well in this site. Therefore, the latter part was optimized in order to improve the potency of the compound and reduce its toxicity.

\section{Initial kinetic analysis of Compound 54 derivatives}

In the first step, twenty derivatives were made and evaluated for the EscN ATPase inhibition (Table 2). Biochemical tests revealed four compounds that were able to reduce EscN ATPase activity by at least 15\%: Compounds 54.6, 54.10, 54.11 and 54.12. The values were lower than for Compound 54 which showed $24 \pm 7 \%$ inhibition at $100 \mu \mathrm{M}$ concentration. Analysis of bacterial cell growth in the presence of $100 \mu \mathrm{M}$ compounds did not show any bacteriostatic effect on the growth curve (Fig. S3, Supplementary Information at www.actabp.pl).

ATP hydrolysis test was performed at $100 \mu \mathrm{M}$ inhibitor concentration with recombinant $\mathrm{EscN}$ protein using a coupled phosphorylase assay EnzCheck as described under Materials and Methods. Relative inhibition was measured versus the activity of EscN ATPase in the absence of inhibitors. Values are mean \pm S.D. $(n=3)$.

Analysis of inhibition type was performed at higher Figure 7. Compounds 54 and 26 do not block bacterial growth. (Panel A) Compounds 9 and 26, (Panel B) Compounds 42 and 54, (Panel C) Compound 56. EPEC were grown in 96-well plates in DMEM medium with constant shaking at $37^{\circ} \mathrm{C}$ in the presence of $100 \mu \mathrm{M}$ concentration of inhibitor. Cell density was adjusted for $1 \mathrm{~cm}$ path length. Red line - wt EPEC, blue line - wt EPEC in the presence of inhibitor. Values are means and the error bars reflect the range between the minimum and maximum values. Arrows under each graph indicate the $2 \mathrm{hrs}$ time points at which secretion of EspG effector was measured in later experiments.
(0.6 and $1.2 \mathrm{mM}$ ) ATP concentrations due to the low signal-to-noise ratios at concentrations below $K_{\mathrm{m}}$. The values (Table 3 ) showed that only the Compound 54.6 was a noncompetitive inhibitor. The best competitive inhibitors had $K_{\mathrm{i}}$ values of approximately $500 \mu \mathrm{M}$. 
Table 2. List of synthetic analogs of Compound 54 selected for the first optimization.

\begin{tabular}{|c|c|c|c|}
\hline Entry & ID & $\begin{array}{l}\text { Relative EscN } \\
\text { Inhibition, \% } \\
\end{array}$ & Structure \\
\hline 1 & 54.1 & $2 \pm 2$ & \\
\hline 2 & 54.2 & $-8 \pm 4$ & \\
\hline 3 & 54.3 & $3 \pm 2$ & \\
\hline 4 & 54.4 & $5 \pm 9$ & \\
\hline 5 & 54.5 & $1 \pm 7$ & \\
\hline 6 & 54.6 & $15 \pm 1$ & \\
\hline 7 & 54.7 & $2 \pm 7$ & \\
\hline 8 & 54.8 & $4 \pm 5$ & \\
\hline 9 & 54. 9 & $-2 \pm 7$ & \\
\hline 10 & 54.10 & $16 \pm 2$ & \\
\hline 11 & 54.11 & $12 \pm 5$ & \\
\hline 12 & 54.12 & $17 \pm 5$ & \\
\hline 13 & 54.13 & $-13 \pm 6$ & \\
\hline
\end{tabular}

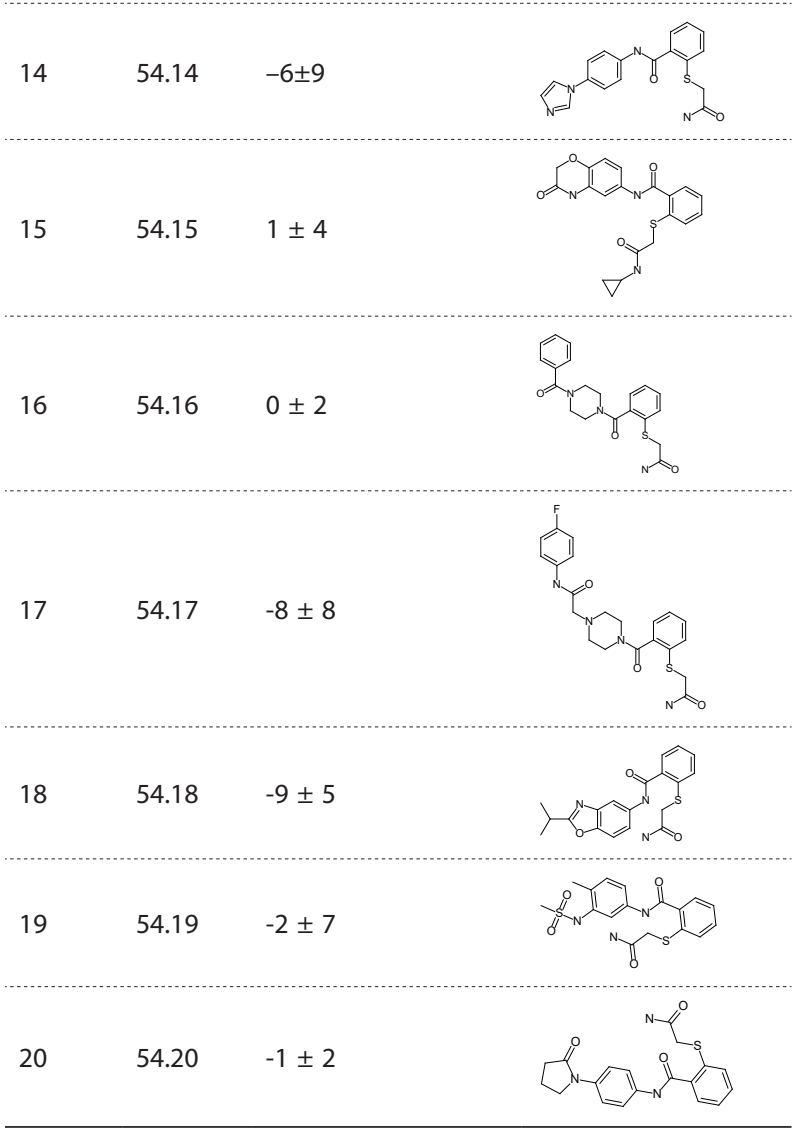

\section{Additional kinetic screening of extended rage of Compound 54 derivatives}

At this stage, we decided to extend our range of derivatives of Compound 54 by examining more substitutions within the core of Compound 54. After screening additional derivatives at $100 \mu \mathrm{M}$ concentration in the ATP hydrolysis test as before, we selected 4 additional derivatives (Fig. 8) to determine the type of inhibition (Fig. 9 and Table 4). The best inhibitor was WEN05-03 $\left(K_{\mathrm{i}}=16 \pm 2 \mu \mathrm{M}, \mathrm{SD}, \mathrm{n}=2\right)$ followed by the WEN04-34 $\left(K_{\mathrm{i}}=46 \pm 2 \mu \mathrm{M}, \mathrm{SD}, \mathrm{n}=2\right)$. The latter was a derivative of one of the initial hits selected from shape recognition search while the former was designed based on systematic changes of selected parts.

One-way ANOVA analysis of the inhibition screening data (Fig. 8) demonstrated that all inhibition data were statistically valid. The data for WEN04-34 and WEN0503 had $p<0.005$ when compared to the uninhibited en-

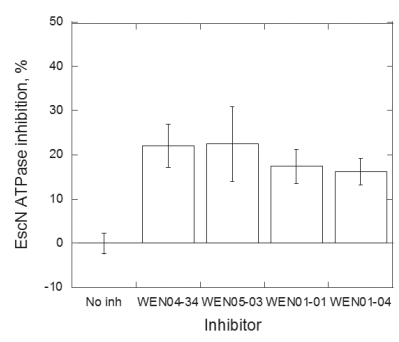

Figure 8. WEN05-03 and WEN04-34 are the best EscN ATPase inhibitors in the initial screening.

The inhibitors were screened at $100 \mu \mathrm{M}$ concentration in the EnzCheck coupled hydrolysis assay. Measurements were performed at R.T. as described under Materials and Methods. Error bars reflect $\operatorname{SD}(n=2)$. 
Table 3. Measured $K_{\mathrm{i}}$ values for top derivatives of Compound 54.

\begin{tabular}{llll}
\hline Entry & ID & $K_{\mathrm{i}^{\prime}} \mu \mathrm{M}$ & Inhibition type \\
\hline 1 & 54.6 & 3500 & Noncompetitive \\
\hline 2 & 54.10 & $500 \pm 310$ & Competitive \\
\hdashline 3 & 54.11 & $255 \pm 61$ & Competitive \\
\hdashline 4 & 54.12 & $550 \pm 14$ & Competitive \\
\hdashline 5 & 54 & $475 \pm 57$ & Competitive \\
\hline 6 & 26 & n.d. ${ }^{\mathrm{b}}$ & n.d. ${ }^{\mathrm{b}}$ \\
\hline
\end{tabular}

ATP hydrolysis inhibition was determined with EnzCheck Pyrophosphatase Assay kit (Life Technologies) at R.T. as described under Materials and Methods. Values of $K_{\mathrm{i}}$ are mean $\pm \mathrm{SD}(\mathrm{n}=2)$. aClassification of inhibition as noncompetitive is based on the very high calculated $K_{i}$ value. ${ }^{b}$ Compound 26 precipitated at concentrations above $100 \mu \mathrm{M}$ which precluded determination of its inhibitory properties. n.d. - not determined.

zyme while WEN01-01 and WEN01-04 had $p<0.05$. In both cases, the confidence level was above $95 \%$.

Compounds 54.5 and 54.2 were also screened for bacterial growth inhibition. Unfortunately, the compounds did not inhibit EPEC growth at $100 \mu \mathrm{M}$ concentration when tested over $24 \mathrm{hrs}$ period (W. Swietnicki, unpublished data). The same results were observed for WEN inhibitor series.

\section{Evaluation of extended range Compound 54 derivatives for blockage of T3SS secretion and cellular toxicity}

In the next step, we examined the top derivatives from Table 4 for their ability to block EspG secretion. Unfortunately, due to the variability of results when using the high sensitivity Femto West detection system, the quantification was not possible. It could have been due to the very low expression level of EspG by the pathogen.

The derivatives of Compound 54 were also examined for their potential toxicity in a multitude of assays in HeLa cells (Fig. 10). In general, all selected compounds had no discernible effect on cellular viability as measured
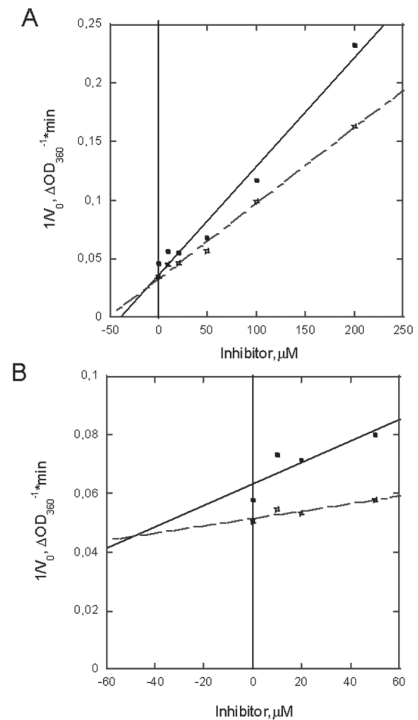

Figure 9. WEN05-03 and WEN04-34 are competitive inhibitors of EscN ATPase.

Representative plots are shown for 2 best inhibitors, WEN05-03 (Panel A) and WEN04-34 (Panel B). Measurements were performed at R.T. using a coupled assay as described under Materials and Methods. $[$ ATP $]=0.6 \mathrm{mM}, \square[\mathrm{ATP}]=1.2 \mathrm{mM}$. by flow cytometry (Fig. 10A). The results were similar when examining mitochondrial potential (Fig. 10B). All derivative compounds exhibited very small mitochondrial potential interference and obtained values were very close to the values measured for the solvent alone. The results are in contrast to data for the original Compound 54 which showed a very significant interference with mitochondrial potential at $100 \mu \mathrm{M}$ concentration which would clearly disqualify it from further tests. However, cell viability in the presence of Compound 54 and its derivatives showed that none of the compounds caused significant cell death at $100 \mu \mathrm{M}$ concentration. Therefore, the viability test was not as discriminatory as the other tests.

Tests for cell apoptosis induction based on caspase activity measurements (Fig. 10C) demonstrated a very small $(15 \%$ or below) induction, practically indistinguishable from the solvent control. On the other hand, analysis of apoptosis induction by Annexin $\mathrm{V}$ marker (Fig. 10D) showed more varied results. At $100 \mu \mathrm{M}$
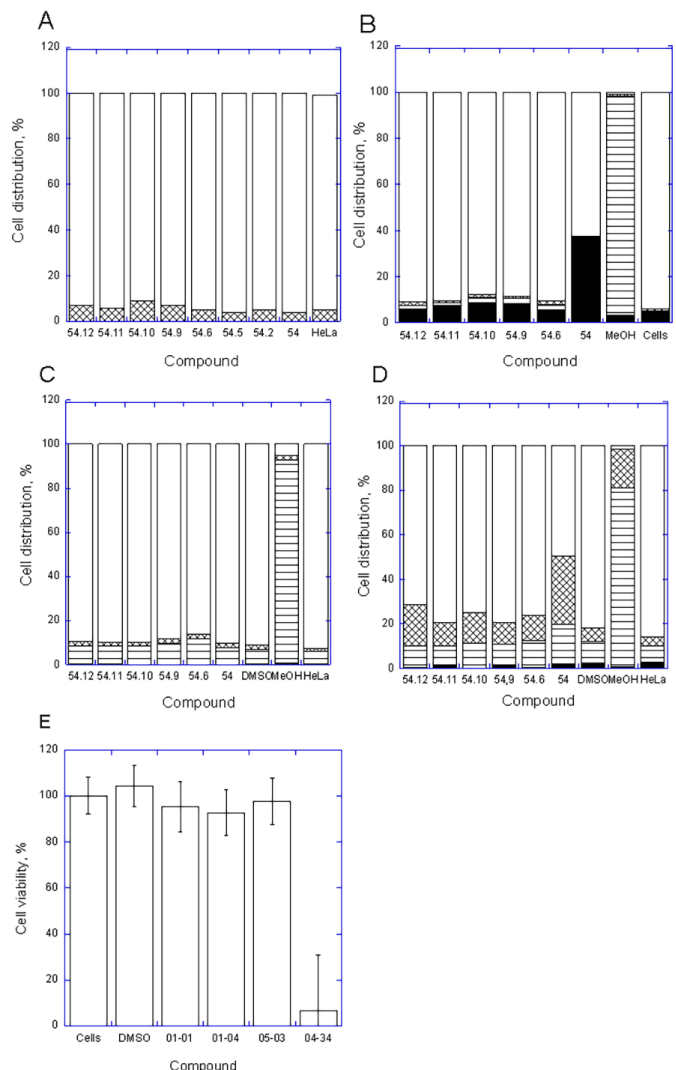

Figure 10. Derivatives of Compound 54 have significantly diminished cellular toxicity.

(Panel A) Cell viability. White bars - live cells, crosshatched cells - dead cells. (Panel B) Mitochondrial potential interference. Clear bars - live cells, crosshatched cells - depolarized live cells, hatched bars - depolarized/dead cells, black bars - dead cells. (Panel C) General apoptosis by caspase activity. Black bars - dead cells, crosshatched bars - caspase-positive cells, hatched bars caspase-positive/dead cells, clear bars - live cells. (Panel D) Apoptosis by Annexin V marker. Clear bars - live cells, crosshatched bars - cells during early apoptosis, hatched bars - cells during late apoptosis, black bars - dead cells. Cell distribution was measured by flow cytometry on a MUSE (Merck) system using recommended kits (Merck). (Panel E) Cell viability by MTT. Cell viability was measured by MTT test. Inhibitor concentration in all assays was $100 \mu \mathrm{M}$. Details are under Materials and Methods. Reported values for MTT tests are means $\pm S D(n=2)$. For the flow cytometry measurements, the reported values are the means from at least 1000 cell counting events per experiment. 
Table 4. Measured $K_{\mathrm{i}}$ values for top derivatives after optimization.

\begin{tabular}{|c|c|c|c|c|}
\hline Entry & ID & Structure & $K_{\mathrm{i},}, \mu \mathrm{M}$ & $\begin{array}{l}\text { Inhibition } \\
\text { type }\end{array}$ \\
\hline 1 & WEN01-01 & & $470 \pm 78$ & Competitive \\
\hline 2 & WEN01-04 & & $440 \pm 207$ & Competitive \\
\hline 3 & WEN04-34 & & $46 \pm 2$ & Competitive \\
\hline 4 & WEN05-03 & & $16 \pm 2$ & Competitive \\
\hline
\end{tabular}

ATP hydrolysis inhibition and $K_{\mathrm{i}}$ values were determined with EnzCheck Pyrophosphatase Assay kit (Life Technologies) at R.T. as described under Materials and Methods. Table shows means \pm SD $(n=2)$. aCompound WEN04-34 was selected from an existing database based on similarity to Compound 54 using aPhase shape screening module with a shape similarity index of 0.7 .

concentration of Compound 54, there was a very pronounced early apoptosis (50\% of analyzed cells). Compound 54 derivatives, however, had the rate of apoptosis markedly reduced and approaching values observed for the solvent alone. The results mirrored data for cell cycle analysis.

To extend toxicity tests, all experiments were repeated for a non-cancer cell line BALB/3T3. The data confirmed that Compound 54 derivatives had a significantly reduced toxicity and a diminished influence on the cells as compared to the original molecule (Fig. S4-S6 at www.actabp.pl).

Inclusion of the MTT test was important to avoid artifacts associated with flow cytometry which measured only the surviving cells as opposed to the MTT test measuring overall metabolism for cells in a given well. However, the test is very general and cannot detect specific problems as opposed to the specialized flow cytometry tests, e.g. cell cycle interference, mitochondrial potential interference or apoptosis induction.

For Compound 54, the toxicity was revealed only at the stage of mitochondrial potential interference (Fig. 10B) and earlier at the apoptosis induction (Fig. 4B) but not in the MTT tests.

The two best hits from the EscN activity assay, WEN05-03 and WEN04-34, differed between each other in cytotoxicity tests. WEN05-03 was non-toxic and showed only $7 \%$ growth inhibition at $100 \mu \mathrm{M}$ concentration on BALB/3T3 cells as determined by MTT assay, while the WEN04-34 compound was highly toxic and inhibited growth by more than $90 \%$ in the same assay (Fig. 10E). The data for both compounds were reflected in tests for interference with cell cycle, mitochondrial potential, induction of apoptosis and a general viability, including MTT test, using a HeLa cell line (data not shown). Therefore, the compound WEN05-03 was selected for further experiments.

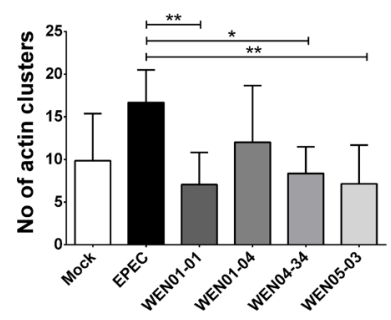

Figure 11. Inhibition of actin cluster formation in EPEC-infected HeLa cells by WEN compounds.

HeLa cell line was infected with EPEC at the MOI 20:1 in the presence of $100 \mu \mathrm{M}$ inhibitors Actin clusters (size range of 5-20 $\mathrm{mm}^{2}$ ) were counted $2 \mathrm{hrs}$ post-infection using data from 7 fields of view (20x objective) as described under Materials and Methods. Bars correspond to the mean values with standard deviation. Asterisks show statistical significance $\left({ }^{*} p<0.05 ;{ }^{* *} p<0.01\right)$ identified with ANOVA test (shown are comparison to EPEC group). Mock - solvent treated Hela cells, EPEC - cells with EPEC.

\section{Evaluation of selected optimized inhibitors for blockage of cell destruction by EPEC}

To address the influence of Compound 54 and its derivatives on the EPEC infection of HeLa cells, we used wide-field and confocal microscopy - the latter combined with semi-automatic image analysis. We visualized actin clustering to assess inhibitory activity of tested compounds, which is consistent with a model where first filopodia and later pedestal formation are required for bacterial internalization (Berger et al., 2009; Jepson et al., 2003). Blockage of their formation blocks the pathogen's entry by induced phagocytosis. Microscopic examination of the clusters confirmed that the accumulations of actin correlated with bacterial cells presence (Fig. S2 at www. actabp.pl). To validate our quantitative assay, we measured local concentration of actin filaments in control (non-infected) cells and in cells infected with wt EPEC and $\operatorname{DescN}$ mutant EPEC. For the analysis, we took actin clusters ranging in size between 0.9 and $25 \mu \mathrm{m}^{2}$ as the size of free bacteria clusters on plastic was on average 3.6 \pm 3.6 $\mu \mathrm{m}^{2}$ ( \pm standard deviation) (based on wide-field images). As expected, there was an increase in actin clustering in HeLa cells infected with EPEC compared to mock-treated cells - on average 4 times higher number of actin clusters in the size range of 5-20 $\mathrm{mm}^{2}$ (Fig. S7 at www.actabp. $\mathrm{pl}$ and data not shown). Also, DescN mutant of EPEC induced fewer actin pedestals than wt EPEC (2-fold decrease, data not shown). After such a validation of the assay, we tested selected inhibitors and obtained data indicated that some compounds (especially Compound 54.6 and 54) showed a trend to reduce the number of actin clusters; however, using ANOVA test the drop was not statistically significant (data not shown). The optimized compounds from the WEN series were also used in the same test (Fig. 11). Compounds WEN01-01, WEN04-34 and WEN05-03 reduced pedestal formation to the level of mock-treated HeLa cells proving successful optimization of the Compound 54 derivatives. The effect was statistically significant when tested using one-way ANOVA.

\section{Virtual analysis of predicted binding mode of WEN05- 03 inhibitor in the active site of EscN ATPase}

To help us understand inhibition properties of selected inhibitors, we analyzed the virtual complex structure of EscN protein and compound WEN05-03, which was the best competitive inhibitor of EscN and infection blocker, as visualized by the pedestal formation assay. Analysis of 


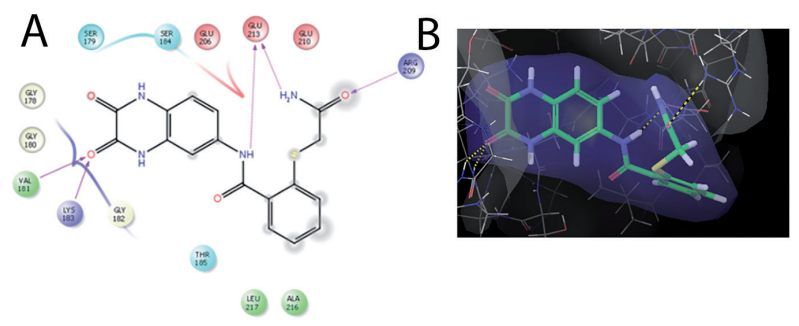

Figure 12. Virtual docking pose of WEN05-03 in the active site of $\mathrm{EscN}$.

(Panel A) Diagram of ligand interactions in the active site of EscN ATPase. Modelled hydrogen bonds are marked with red arrow lines pointing from donor to acceptor. Positively charged molecular surface boundary lines are colored in blue while the negatively charged molecular surface boundary lines are colored in red. Residues in circles have background fillings colored according to the residue charge: blue for positive, red for negative and white for neutral. Gray circles around ligand atoms denote potential exposure to solvent (atoms not buried). Size of the circle relates to the degree of solvent exposure. (Panel B) Docking pose of WEN05-03 in the active site. Molecular surface of receptor is colored in gray while the surface of ligand is colored in blue. Ligand is drawn in thick lines. Modelled hydrogen bonds between the ligand and the receptor are marked with dashed yellow lines. Ligand atom colors: red-O, white- $\mathrm{H}$, blue- $\mathrm{N}$, green- $\mathrm{C}$, yellow- $\mathrm{C}$. Receptor atom colors: grey- $\mathrm{C}$, red-O, blue- $\mathrm{N}$, yellow-S, white- $\mathrm{H}$. Bond order is denoted by the number of bars connecting atoms. Figures were prepared with the Schroedinger molecular modeling software suite (Schroedinger LLC).

interactions in the active site suggested 5 possible hydrogen bonds (Fig. 12). The ligand appears to fit well in the active site and extra stabilization by proposed hydrogen bonds with the backbone and side chains of the protein in the middle of the ligand (Glu213), at the carboxamide side chain group (Glu213, Arg209) and the opposite end to the keto group of the ring (Gly180, Val181 and Lys182) would support the lowest $K_{\mathrm{i}}$ value measured.

\section{DISCUSSION}

Development and use of bacterial antibiotics in the last 50 years contributed significantly to the reduction of mortality rates in human and animal population. Success of the strategy and access to many common antibiotics led to their massive use, in farm animals as well as in human population, which eventually brought us to a crisis: many common pathogens could easily bypass the existing antibiotics and new ways to treat bacterial infections have not appeared fast enough to counter the resistance. Therefore, novel, radical strategies have to be develop to eliminate or lower significantly potential resistance from drugs. The drug targets also have to be selected differently to remove resistance pressure normally encountered in antibiotic therapy. In our approach, we present such an approach and describe the first study on optimization of small molecule compounds against an ATPase from a bacterial virulence system.

In the recent years, two main classes of antibiotics emerged as the only options: the $\beta$-lactamase inhibitors and the gyrase/topoisomerase IV inhibitors. The former drugs are based on non-metal binding catalytic site and the recent emergence of a metal-binding catalytic site practically invalidated many of the antibiotics from this class (Murphy et al., 2006). The gyrase/topoisomerase IV inhibitors, on the other hand, face toxicity problems (Strahilevitz et al., 2009) and resistance connected to the drug-removal efflux pumps in bacteria (Johnson et al., 2013; Strahilevitz et al., 2009; Robicsek et al., 2006), making them of limited use in human population. Therefore, both classes of antibiotics may have to be rethought for future antibacterial therapies. A differ- ent strategy, based on non-antibiotics, may offer an option. The strategy would target offensive weaponry of pathogens instead of the vital functions and let the host remove the inactivated pathogens (Duncan et al., 2012; Fletcher et al., 2010). As such, the pathogen will not be pressured to develop resistance and existing antibiotic resistance could be easily bypassed. The approach is novel and potentially offers an alternative to antibiotics. The compounds could be used to eliminate drug-resistant pathogens, engineered deliberately or evolved naturally, and change thinking about antibacterial approaches. Considering low selection pressure, the drugs could potentially be used repeatedly over a long period of time without developing resistance. Therefore, the compounds could be accessible to lower income populations in many developing countries. Cost of development would also be lowered since long term use would eliminate the need for changes necessary to counter emerging resistance.

Based on the DNA sequences data available for many pathogens, there are six major virulence systems of pathogens (http://www.genome.jp/kegg-bin/show_ pathway?map03070) with the seventh discovered recently (Abdallah et al., 2007). Each type has an ATPase, sometimes 2 or more, and their functions have been known relatively well. The T3SS is the most common in bacteria and the most studied. It has a single ATPase which can be used as a drug target or as a target for live, genetically engineered vaccine (Bozue et al., 2012). The enzymes are highly homologous (Fig. 8, Supplemental Information at www.actabp.pl) and development of drugs against one target may lead to a broad-spectrum therapeutics.

In the present work, ATPase from the EPEC was used as a template to develop selective, non-toxic inhibitors capable of blocking the enzyme and, ultimately, blocking the virulence of the pathogen. The compounds were found by screening the ZINC library and tested for inhibition of the enzyme. Most of the compounds (60/72) were either toxic to mammalian cells or non-inhibitory. The probable cause of toxicity may be due to the restriction of the search to drug-like candidates which excludes compounds with larger masses and high flexibility as determined by the number of rotational bonds. The restriction is justified as compounds with larger masses generally have poor bioavailability and the high flexibility would limit their selectivity. Additionally, computer search algorithms perform poorly when the number of rotatable bonds reaches 13 which is expected for larger and more selective inhibitors. Therefore, the chosen strategy was justified.

The wt EscN enzyme is most likely hexameric in its biologically active form (Andrade et al., 2007; Kawamoto et al., 2013), similar to the flagellar system (Ghosh et al., 2011) and the plant-like T3SS (Pozidis et al., 2003). The compounds chosen for testing in the first screening assays (Table 1 and 2) were examined against a most likely dimeric form of the enzyme (Zarivach et al., 2007 and suggested by the kinetic measurements in Fig. 2, insert). However, the oligomerization state of the construct used in the current work was not measured. It is possible that compounds binding to the interaction surfaces in the hexamer/dimer could have been excluded at the initial stage of computational screening due to the search area limitations.

Another option for inhibition would be to block active site in the assembled oligomer. The dimeric form for of enzyme was most likely naturally present during assay conditions and the data should reflect blockage of catalytic activity of such a form. However, screening of compounds against an isolated hexameric form of an enzyme in a dynamic equilibrium with a monomeric form would be impractical and was not attempted in the current work. 
The other aspect connected with hexamerization of the wt EscN enzyme is synergy of inhibition. Relatively weak inhibitors could be very effective in biological assays, presumably due to the simultaneous binding to each of the subunits. The effect was demonstrated when comparing data for the same compounds in ATP hydrolysis and actin cluster formation blockage assays.

The final test of selected compounds, inhibition of toxic effects to a mammalian cell culture in the HeLa cell infection model, showed that compounds capable of blocking ATP hydrolysis were effective in blocking EPEC-induced toxicity to cells (Fig. 9, Fig. 10). The most effective were compounds WEN01-01 and WEN05-03 which could also reduce pedestal formation (Fig. 11).

Analysis of the structures of the two best compounds did not reveal similarity to existing T3SS inhibitors (Duncan et al., 2012). This fact might be due to the diversity of targets or lack of specific ones. The only existing inhibitors specifically targeting ATPase were identified previously (Swietnicki et al., 2011) but they were not effective against EscN (W. Swietnicki, unpublished data). Therefore, testing of inhibitors against other ATPases from bacterial T3SSs was not performed. The compounds were much bigger than the WEN series compounds developed in the current work and with more rotatable bonds, potentially making one of the conformers highly specific for $\mathrm{YscN}$ but much less for EscN. The ligand molecular weight and flexible bond number limit for the compounds in the current work were determined at the stage of database selection (ZINC drug-like candidates) and, additionally, during the computational screening. Therefore, the strategy selected in the current work identified compounds more suitable for drug development. Additionally, the compounds were non-toxic after optimization which proved the hypothesis that small molecule inhibitors against active site of bacterial ATPases can be selective. Increase in metabolic stability by eliminating easily cleavable bonds (e.g., peptide bond in derivatives of Compound 54) could prevent compounds from becoming a potential nutrient for the pathogen and lead to decrease in therapeutic doses. Future work on the presented compounds may lead to other inhibitors with a broader spectrum, higher potency against bacterial T3SSs and a low potential for developing resistance. The drugs could be safe and selective for pathogens only.

\section{Acknowledgements}

The authors would like to thank Dr. Annette Hoeglund from Schroedinger LLC for generous help with software licenses during testing stages, the IT department at Wroclaw Research Centre EIT+, Wroclaw, PL for help with setting up computational facilities required for the work, Wroclaw Centre for Networking and Supercomputing, Wroclaw, PL for help with the final aspects of computational screening, W. Rybka and Prof. A. Gamian from the Institute of Immunology and Experimental Therapy of the Polish Academy of Sciences, Wroclaw, PL for coordinating many aspects of the work at the Institute of Immunology and Experimental Therapy of the Polish Academy of Sciences, Wroclaw, PL.

Cost of publication was covered by project 501-15 from the Institute of Immunology.

\section{REFERENCES}

Abdallah AM, Gey van Pittius NC, Champion PA, Cox J, Luirink J, Vandenbroucke-Grauls C M, Appelmelk BJ, Bitter W (2007) Type VII secretion - mycobacteria show the way. Nat Rev Microbiol 5: 883-891. https://doi.org/10.1038/nrmicro1773
Andrade A, Pardo JP, Espinosa N, Perez-Hernandez G, Gonzalez-Pedrajo B (2007) Enzymatic characterization of the enteropathogenic Escherichia coli type III secretion ATPase EscN. Arch Biochem Biophys 468: 121-127. https://doi.org/10.1016/j.abb.2007.09.020

Berger CN, Crepin VF, Jepson MA, Arbeloa A, Frankel G (2009) The mechanisms used by enteropathogenic Escherichia coli to control filopodia dynamics Cell Microbiol 11: 309-322. http://doi. org/10.1111/j.1462-5822.2008.01254.x

Blaylock B, Riordan KE, Missiakas DM, Schneewind O (2006) Characterization of the Yersinia enterocolitica type III secretion ATPase YscN and its regulator, YscL. J Bacteriol 188: 3525-3534. http://doi. org/10.1128/jb.188.10.3525-3534.2006

Bozue J, Cote CK, Webster W, Bassett A, Tobery S, Little S, Swietnicki W (2012) A Yersinia pestis YscN ATPase mutant functions as a live attenuated vaccine against bubonic plague in mice. FEMS Microbiol Lett 332: 113-121. http://doi.org/10.1111/j.1574-6968.2012.02583.x

Chen L, Ai X, Portaliou AG, Minetti CA, Remeta DP, Economou A, Kalodimos CG (2013) Substrate-activated conformational switch on chaperones encodes a targeting signal in type III secretion. Cell Rep 3: 709-715. http://doi.org/10.1016/j.celrep.2013.02.025

Cornelis GR (2006) The type III secretion injectisome. Nat Rev Microbiol 4: 811-825. http://doi.org/10.1038/nrmicro1526

Cowan C, Philipovskiy AV, Wulff-Strobel CR, Ye Z, Straley SC (2005) Anti-LcrV antibody inhibits delivery of Yops by Yersinia pestis KIM5 by directly promoting phagocytosis. Infec Immun 73: 61276137. http://doi.org/10.1128/iai.73.9.6127-6137.2005

Davis AJ, Díaz DA, Mecsas J (2010) A dominant-negative needle mutant blocks type III secretion of early but not late substrates in Yersinia. Mol Microbiol 76: 236-259. http://doi.org/10.1111/j.13652958.2010.07096.x

Diepold A, Amstutz M, Abel S, Sorg I, Jenal U, Cornelis GR (2010) Deciphering the assembly of the Yersinia type III secretion injectisome. EMBO J 29: 1928-1940. http://doi.org/10.1038/emboj. 2010.84

Diepold A, Wiesand U, Cornelis GR (2011) The assembly of the export apparatus (YscR,S,T,U,V) of the Yersinia type III secretion apparatus occurs independently of other structural components and involves the formation of an YscV oligomer. Mol Microbiol 82: 502514. http://doi.org/10.1111/j.1365-2958.2011.07830.x

Dixon M (1953) The determination of enzyme inhibitor constants. Biochem J 55: 170-171. http://doi.org/10.1042/bj0550170

Duncan MC, Linington RG, Auerbuch V (2012) Chemical inhibitors of the type three secretion system: disarming bacterial pathogens. Antimicrob Agents Chemother 56: 5433-5441. http://doi.org/10.1128/ aac.00975-12

Edwards PR, Ewing WH (1972) Identification of Enterobacteriaceae, 3rd edn, Burgess Publishing Co.

Eichelberg K, Ginocchio CC, Galán JE (1994) Molecular and functional characterization of the Salmonella typhimurium invasion genes invB and invC: homology of InvC to the F0F1 ATPase family of proteins. J Bacteriol 176: 4501-4510. http://doi.org/10.1128/ jb.176.15.4501-4510.1994

Feltcher ME, Sullivan JT, Braunstein M (2010) Protein export systems of Mycobacterium tuberculosis: novel targets for drug development? Future Microbiol 5: 1581-1597. http://doi.org/10.2217/fmb.10.112

Friesner RA, Banks JL, Murphy RB, Halgren TA, Klicic JJ, Mainz DT, Repasky MP, Knoll EH, Shelley M, Perry JK, Shaw DE, Francis P, Shenkin PS (2004) Glide: a new approach for rapid, accurate docking and scoring. 1. Method and assessment of docking accuracy. $J$ Med Chem 47: 1739-1749. http://doi.org/10.1021/im0306430

Friesner RA, Murphy RB, Repasky MP, Frye LL, Greenwood JR, Halgren TA, Sanschagrin PC, Mainz DT (2006) Extra precision glide: docking and scoring incorporating a model of hydrophobic enclosure for protein-ligand complexes. J Med Chem 49: 6177-6196. http://doi.org/10.1021/jm051256o

Garrity-Ryan LK, Kim OK, Balada-Llasat JM, Bartlett VJ, Verma AK, Fisher ML, Castillo C, Songsungthong W, Tanaka SK, Levy SB, Mecsas J, Alekshun MN (2010) Small molecule inhibitors of LcrF, a Yersinia pseudotuberculosis transcription factor, attenuate virulence and limit infection in a murine pneumonia model. Infec Immun 78: 4683-4690. http://doi.org/10.1128/iai.01305-09

Gartner JF, Schmidt MA (2004) Comparative analysis of locus of enterocyte effacement pathogenicity islands of atypical enteropathogenic Escherichia coli. Infec Immun 72: 6722-6728. http://doi. org/10.1128/iai.72.11.6722-6728.2004

Gauthier A, Finlay BB (2003) Translocated intimin receptor and its chaperone interact with ATPase of the type III secretion apparatus of enteropathogenic Escherichia coli. J Bacteriol 185: 6747-6755. http://doi.org/10.1128/jb.185.23.6747-6755.2003

Germane KL, Spiller BW (2011) Structural and functional studies indicate that the EPEC effector, EspG, directly binds p21-activated kinase. Biochemistry 50: 917-919. http://doi.org/10.1021/bi1020138

Ghosh A, Hartung S, van der Does C, Tainer JA, Albers SV (2011) Archaeal flagellar ATPase motor shows ATP-dependent hexameric assembly and activity stimulation by specific lipid binding. Biochem J 437: 43-52. http://doi.org/10.1042/bj20110410 
Grier MC, Garrity-Ryan LK, Bartlett VJ, Klausner KA, Donovan PJ, Dudley C, Alekshun MN, Tanaka SK, Draper MP, Levy SB, Kim OK (2010) N-Hydroxybenzimidazole inhibitors of ExsA MAR transcription factor in Pseudomonas aeruginosa: In vitro anti-virulence activity and metabolic stability. Bioorg Med Chem Lett 20: 3380-3383. http://doi.org/10.1016/j.bmcl.2010.04.014

Gust B, Challis GL, Fowler K, Kieser T, Chater KF (2003) PCRtargeted Streptomyces gene replacement identifies a protein domain needed for biosynthesis of the sesquiterpene soil odor geosmin. Proc Natl Acad Sci US A 100: 1541-1546. http://doi.org/10.1073/ pnas. 0337542100

Halgren TA, Murphy RB, Friesner RA, Beard HS, Frye LL, Pollard WT, Banks JL (2004) Glide: a new approach for rapid, accurate docking and scoring. 2. Enrichment factors in database screening. I Med Chem 47: 1750-1759. http://doi.org/10.1021/jm030644s

Hou T, Wang J, Li Y, Wang W (2011a) Assessing the performance of the MM/PBSA and MM/GBSA methods. 1. The accuracy of binding free energy calculations based on molecular dynamics simulations. J Chem Inf Model 51: 69-82. http://doi.org/10.1021/ci100275a

Hou T, Wang J, Li Y, Wang W (2011b) Assessing the performance of the molecular mechanics/Poisson Boltzmann surface area and molecular mechanics/generalized Born surface area methods. II. The accuracy of ranking poses generated from docking. I Comput Chem 32: 866-877. http://doi.org/10.1002/jcc.21666

$\mathrm{Hu}$ X, Vujanac M, Southall N, Stebbins CE (2013) Inhibitors of the Yersinia protein tyrosine phosphatase through high throughput and virtual screening approaches. Bioorg Med Chem Lett 23: 1056-1062. http://doi.org/10.1016/j.bmcl.2012.12.018

Iguchi A, Thomson NR, Ogura Y, Saunders D, Ooka T, Henderson IR, Harris D, Asadulghani M, Kurokawa K, Dean P, Kenny B, Quail MA, Thurston S, Dougan G, Hayashi T, Parkhill J, Frankel G (2009) Complete genome sequence and comparative genome analysis of enteropathogenic Escherichia coli O127:H6 strain E2348/69. J Bacteriol 191: 347-354. http://doi.org/10.1128/jb.01238-08

Izore T, Job V, Dessen A (2011) Biogenesis, regulation, and targeting of the type III secretion system. Structure 19: 603-612. http://doi. org/10.1016/j.str.2011.03.015

Jepson MA, Pellegrin S, Peto L, Banbury DN, Leard AD, Mellor H, Kenny B (2003) Synergistic roles for the Map and Tir effector molecules in mediating uptake of enteropathogenic Escherichia coli (EPEC) into non-phagocytic cells. Cell Microbiol 5: 773-783. http:// doi.org/10.1046/j.1462-5822.2003.00315.x

Johnson JR, Tchesnokova V, Johnston B, Clabots C, Roberts PL, Billig M, Riddell K, Rogers P, Qin X, Butler-Wu S, Price LB, Aziz M, Nicolas-Chanoine MH, Debroy C, Robicsek A, Hansen G, Urban C, Platell J, Trott DJ, Zhanel G, Weissman SJ, Cookson BT, Fang FC, Limaye AP, Scholes D, Chattopadhyay S, Hooper DC, Sokurenko EV (2013) Abrupt emergence of a single dominant multidrug-resistant strain of Escherichia coli. I Infec Dis 207: 919-928. http://doi.org/10.1093/infdis/jis933

Kawamoto A, Morimoto YV, Miyata T, Minamino T, Hughes KT, Kato T, Namba K (2013) Common and distinct structural features of Salmonella injectisome and flagellar basal body. Sci Rep 3: 3369. http://doi.org/10.1038/srep03369

Keyser P, Elofsson M, Rosell S, Wolf-Watz H (2008) Virulence blockers as alternatives to antibiotics: type III secretion inhibitors against Gram-negative bacteria. J Intern Med 264: 17-29. http://doi. org/10.1111/j.1365-2796.2008.01941.x

Li J, Abel R, Zhu K, Cao Y, Zhao S, Friesner RA (2011) The VSGB 2.0 model: a next generation energy model for high resolution protein structure modeling. Proteins 79: 2794-2812. http://doi. org/10.1002/prot.23106

Lineweaver H, Burk D (1934) The determination of enzyme dissociation constants. J Am Chem Soc 56: 658-666. http://doi.org/10.1021/ ja01318a036

Marshall, NC, Finlay, BB (2014) Targeting the type III secretion system to treat bacterial infections. Expert Opin Ther Targets 18: 137152. http://doi.org/10.1517/14728222.2014.855199

Martinez-Argudo I, Veenendaal AK, Liu X, Roehrich AD, Ronessen MC, FranzoniG, van Rietschoten KN, Morimoto YV, Saijo-Hamano Y, Avison MB, Studholme DJ, Namba K, Minamino T, Blocker AJ (2013) Isolation of Salmonella mutants resistant to the inhibitory effect of Salicylidene acylhydrazides on flagella-mediated motility. PloS One 8: e52179. http://doi.org/10.1371/journal.pone.0052179

Mills E, Baruch K, Charpentier X, Kobi S, Rosenshine I (2008) Realtime analysis of effector translocation by the type III secretion system of enteropathogenic Escherichia coli. Cell Host Microbe 3: 104-113. http://doi.org/10.1016/j.chom.2007.11.007

Monjaras Feria J, Garcia-Gomez E, Espinosa N, Minamino T, Namba K, Gonzalez-Pedrajo B (2012) Role of EscP (Orf16) in injectisome biogenesis and regulation of type III protein secretion in enteropathogenic Escherichia coli. J Bacteriol 194: 6029-6045. http://doi. org/10.1128/jb.01215-12

Murphy TA, Catto LE, Halford SE, Hadfield AT, Minor W, Walsh TR, Spencer J (2006) Crystal structure of Pseudomonas aeruginosa
SPM-1 provides insights into variable zinc affinity of metallo-beta-lactamases. J Mol Biol 357: 890-903. http://doi.org/10.1016/j. jmb.2006.01.003

Nataro JP, Kaper JB (1998) Diarrheagenic Escherichia coli. Clin Microbiol Rev 11: 142-201.

Orskov F, Orskov I (1992) Escherichia coli serotyping and disease in man and animals. Can J Microbiol 38: 699-704. http://doi.org/10.1139/ $\mathrm{m} 92-115$

Pozidis C, Chalkiadaki A, Gomez-Serrano A, Stahlberg H, Brown I, Tampakaki AP, Lustig A, Sianidis G, Politou AS, Engel A, Panopoulos NJ, Mansfield J, Pugsley AP, Karamanou S, Economou A (2003). Type III protein translocase: $\mathrm{HrcN}$ is a peripheral ATPase that is activated by oligomerization. J Biol Chem 278: 25816-25824. http://doi.org/10.1074/jbc.m301903200

Rastelli G, Del Rio A, Degliesposti G, Sgobba M (2010) Fast and accurate predictions of binding free energies using MM-PBSA and MM-GBSA. J Comput Chem 31: 797-810. http://doi.org/10.1002/ jcc. 21372

Robicsek A, Jacoby GA, Hooper DC (2006) The worldwide emergence of plasmid-mediated quinolone resistance. Lancet Infec Dis 6: 629640. http://doi.org/10.1016/s1473-3099(06)70599-0

Rossier O, Van den Ackerveken G, Bonas U. (2000). HrpB2 and HrpF from Xanthomonas are type III-secreted proteins and essential for pathogenicity and recognition by the host plant. Mol Microbiol 38: 828-838. http://doi.org/10.1046/j.1365-2958.2000.02173.x

Sastry GM, Adzhigirey M, Day T, Annabhimoju R, Sherman W (2013) Protein and ligand preparation: parameters, protocols, and influence on virtual screening enrichments. J Comput Aided Mol Des 27: 221234. http://doi.org/10.1007/s10822-013-9644-8

Sorg JA, Blaylock B, Schneewind O (2006) Secretion signal recognition by YscN, the Yersinia type III secretion ATPase. Proc Natl Acad Sci US A 103: 16490-16495. http://doi.org/10.1073/pnas.0605974103

Stone CB, Johnson DL, Bulir DC, Gilchrist JD, Mahony JB (2008) Characterization of the putative type III secretion ATPase CdsN (Cpn0707) of Chlamydophila pneumoniae. J Bacteriology 190: 6580-6588. http://doi.org/10.1128/jb.00761-08

Strahilevitz J, Jacoby GA, Hooper DC, Robicsek A (2009) Plasmidmediated quinolone resistance: a multifaceted threat. Clin Microbiol Rev 22: 664-689. http://doi.org/10.1128/cmr.00016-09

Swietnicki W, Carmany D, Retford M, Guelta M, Dorsey R, Bozue J, Lee MS, Olson MA (2011) Identification of small-molecule inhibitors of Yersinia pestis Type III secretion system YscN ATPase. PloS One 6: e19716. http://doi.org/10.1371/journal.pone.0019716

Tautz L, Bruckner S, Sareth S, Alonso A, Bogetz J, Bottini N, Pellecchia M, Mustelin T (2005) Inhibition of Yersinia tyrosine phosphatase by furanyl salicylate compounds. J Biol Chem 280: 94009408. http://doi.org/10.1074/jbc.m413122200

Thomas, NA, Deng W, Puente, JL, Frey EA, Yip CK, Strynadka NC, Finlay BB (2005) Ces'T is a multi-effector chaperone and recruitment factor required for the efficient type III secretion of both LEE- and non-LEE-encoded effectors of enteropathogenic Escherichia coli. Mol Microbiol 57: 1762-1779. http://doi.org/10.1111/j.13652958.2005.04802.x

Umanski T, Rosenshine I, Friedberg D (2002) Thermoregulated expression of virulence genes in enteropathogenic Escherichia coli. Microbiology 148: 2735-2744. http://doi.org/10.1099/00221287-148-9-2735

Vaudaux P, Waldvogel FA (1979) Gentamicin antibacterial activity in the presence of human polymorphonuclear leukocytes. Antimicrob Agents and Chemotherapy 16: 743-749. http://doi.org/10.1128/ aac.16.6.743

Welch RA, Burland V, Plunkett G 3rd, Redford P, Roesch P, Rasko D, Buckles, EL, Liou SR, Boutin A, Hackett J, Stroud D, Mayhew GF, Rose DJ, Zhou S, Schwartz DC, Perna NT, Mobley HL, Donnenberg MS, Blattner FR (2002) Extensive mosaic structure revealed by the complete genome sequence of uropathogenic Escherichia coli. Proc Natl Acad Sci U S A 99: 17020-17024. http://doi.org/10.1073/ pnas. 252529799

Wiles TJ, Kulesus RR, Mulvey MA (2008) Origins and virulence mechanisms of uropathogenic Escherichia coli. Exp Mol Pathol 85: 11-19. http://doi.org/10.1016/j.yexmp.2008.03.007

Wong AR, Pearson JS, Bright MD, Munera D, Robinson KS, Lee SF, Frankel G, Hartland EL (2011) Enteropathogenic and enterohaemorrhagic Escherichia coli: even more subversive elements. Mol Microbiol 80: 1420-1438. http://doi.org/10.1111/j.1365-2958.2011.07661.x

Yoshida Y, Miki T, Ono S, Haneda T, Ito M, Okada N. (2014) Functional characterization of the type III secretion ATPase SsaN encoded by Salmonella pathogenicity island 2. PLoS One 9: e94347. http://doi.org/10.1371/journal.pone.0094347

Zarivach R, Vuckovic M, Deng W, Finlay BB, Strynadka NC (2007) Structural analysis of a prototypical ATPase from the type III secretion system. Nat Struc Mol Biol 14: 131-137. http://doi.org/10.1038/ nsmb1196 